\title{
Update on dyslipidemia in hypothyroidism: the mechanism of dyslipidemia in hypothyroidism
}

\author{
Huixing Liu and Daoquan Peng(1) \\ Department of Cardiovascular Medicine, The Second Xiangya Hospital of Central South University, Changsha, Hunan, China
}

Correspondence should be addressed to D Peng: pengdq@csu.edu.cn

\begin{abstract}
Hypothyroidism is often associated with elevated serum levels of total cholesterol, LDL-C and triglycerides. Thyroid hormone (TH) affects the production, clearance and transformation of cholesterol, but current research shows that thyroid-stimulating hormone (TSH) also participates in lipid metabolism independently of TH. Therefore, the mechanism of hypothyroidism-related dyslipidemia is associated with the decrease of TH and the increase of TSH levels. Some newly identified regulatory factors, such as proprotein convertase subtilisin/kexin type 9, angiogenin-like proteins and fibroblast growth factors are the underlying causes of dyslipidemia in hypothyroidism. HDL serum concentration changes were not consistent, and its function was reportedly impaired. The current review focuses on the updated understanding of the mechanism of hypothyroidism-related dyslipidemia.

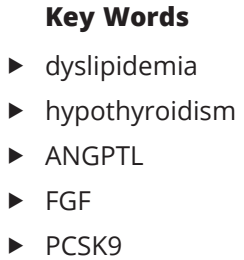

Endocrine Connections (2022) 11, e210002
\end{abstract}

\section{Introduction}

Hypothyroidism, including overt and subclinical hypothyroidism is a common disease among people. The former is defined as increased serum thyroid-stimulating hormone (TSH) levels and reduced free peripheral thyroid hormone (TH) concentrations. The latter is characterized by normal free peripheral $\mathrm{TH}$ concentrations. The association between thyroid dysfunction and dyslipidemia was first reported in 1930. Since then, it has been gradually recognized that hypothyroidism could cause disorders of lipid metabolism (1), mainly with increased total cholesterol (TC) and LDL-C (2) in blood. Elevated LDL-C can lead to progressive lipid accumulation, plaque formation in the arteries and increase the risk of cardiovascular disease (CVD), the leading cause of death worldwide. Regardless of TSH or TC concentration, cholesterol levels will return to normal $(3,4)$ and cardiac function improves $(5)$ after T4 replacement treatment. Furthermore, T4 treatment has a more significant impact on blood lipid profiles in overt than subclinical hypothyroidism (6). Therefore, it is exceedingly important to pay attention to the relationship between hypothyroidism and lipid metabolism.

Previous observations have found that the prevalence of overt hypothyroidism is about $4.3 \%$ (7) and of subclinical hypothyroidism is about $11.1 \%$ (8) among hypercholesterolemic patients, both of which are higher than that of general people. Overt and subclinical hypothyroidism patients with serum TSH $>10 \mathrm{mLU} / \mathrm{L}$ had an increased risk of CVD and mortality (9). These findings suggested that TH and TSH are two important risk factors for lipid metabolic disorders.

$\mathrm{TH}$ is a key regulator of metabolism, development and growth, which plays an important role in regulating the anabolism and catabolism of lipids. However, the deeper mechanism between hypothyroidism and blood lipid profile is still not fully understood, like the signaling pathway of TSH and other regulatory factors involved in lipid disturbance. This review focuses on mechanisms of hypothyroidism related to dyslipidemia, including

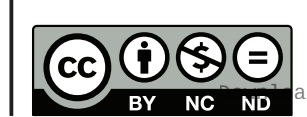

This work is licensed under a Creative Commons Attribution-NonCommercial-NoDerivatives 4.0 Internationab bicense.ifica.com at 04/26/2023 11:49:36AM 
the established mechanisms and the newly identified mechanisms.

\section{Dyslipidemia in hypothyroidism}

Hypothyroidism has a different impact on blood lipid components; generally, it tends to increase levels of TC, especially apolipoprotein B (ApoB)-containing lipoprotein cholesterols, like LDL-C and triglyceride (TG) $(1,10,11)$, while its influence on ApoA-containing lipoprotein cholesterol, like HDL-C, is uncertain (12). However, the ratios of ApoB to ApoA-containing lipoprotein cholesterols (LDL-C/HDL-C and TG/HDL-C) were consistently higher in hypothyroidism than the euthyroid ones $(13,14,15)$. In addition, hypothyroidism patients are more likely to develop postprandial hypertriglyceridemia (16), generally with elevated TG, TG-rich lipoproteins (TRLs) and remnant lipoprotein (RLP).

Hypothyroidism has a different impact on blood lipid profiles. A higher degree of ApoB-containing lipoprotein cholesterols is found in patients with TSH $>10 \mathrm{mLU} / \mathrm{L}$ compared to those with TSH 4.0-10.0 mLU/L (17, 18, 19). Regardless of the thyroid status, circulating TSH level is always positively correlated with levels of ApoB-containing lipoprotein cholesterols $(20,21,22,23,24,25)$. Hence the higher TSH level is, the greater the risks of dyslipidemia are (26). If there is no significant impairment of thyroid function with a low TSH level, blood lipids even improve over time (27). Therefore, we could initially speculate that besides TH, TSH also plays an important role in regulating lipid metabolism.

\section{The mechanism of dyslipidemia in hypothyroidism}

Hypothyroidism influences lipid profiles mainly via $\mathrm{TH}$. $\mathrm{TH}$ could bind to thyroid hormone receptor $\beta$ (THR $\beta$ ), mainly expressed in the liver, to regulate the expression of downstream target genes (28). The total effect of TSH on TC level includes the direct effect and the indirect effect (TH) $(29,30)$. Multiple regression analysis showed that the increase of cholesterol levels was closely related to declined TH levels after injection of TSH in levothyroxinetreated thyroidectomized patients (31). TSH alone also can increase TC levels in CVD patients independent of TH (32). It has been reported that TSH regulates cholesterol metabolism through binding to TSH receptors (TSHRs) on the surface of hepatocytes (33) and adipocytes (34). Therefore, current evidence suggests that both TH and TSH affect cholesterol metabolism. Some regulatory factors are involved in cholesterol metabolism regulating as following. The major effect of TH and TSH on lipid metabolism in hypothyroidism has been outlined in Fig. 1.

\section{Hypothyroidism and LDL-C metabolism}

\section{Hypothyroidism affects the production and clearance of LDL-C}

TH has contradictory effects on cholesterol absorption and production. TH can directly induce the expression of liver HMG-COA reductase (HMGCR), a rate-limiting enzyme in cholesterol synthesis (35), achieving greater cholesterol synthesis (36). Besides binding to THR, TH could activate sterol regulatory element-binding protein 2 (SREBP2) (37), a major transcription factor, and SREBP2 can stimulate the transcription of HMGCR gene. Hence, hypothyroidism can cause reduced cholesterol synthesis by affecting HMGCR. But the effect of TH on the Niemann-Pick C1-like 1 protein (NPC1L1) in the intestine leads to increased cholesterol absorption in hypothyroidism (38). In hypothyroidism, free fatty acid (FFA) oxidation is also reduced, leading to increased very low-density lipoprotein (VLDL) secretion in the liver. TH could enhance $\beta$-oxidation of FFA by increasing the autophagy of hepatocytes (39). It could also stimulate carnitine palmitoyltransferase I $\alpha$ (CPT1A), a rate-limiting $\beta$-oxidation enzyme (40). Accordingly, CPT1A mRNA and enzyme activity in the hyperthyroidism animal livers increase significantly (41); CPT1A is inhibited in the hypothyroidism mice (42). TH can also reduce the production of ApoB48 and ApoB100, thus reducing the production of VLDL and chylomicron (CM) $(43,44)$. Moreover, ApoB48 levels are negatively correlated to $\mathrm{TH}$ (45). Overall, the reduction of $\mathrm{TH}$ inhibits cholesterol synthesis via HMGCR but promotes the absorption of cholesterol through NPC1L1 and reduces catabolism through $\beta$-oxidation.

The LDL receptor (LDLR) is a transmembrane glycoprotein on the hepatocyte surface that recognizes lipoproteins containing ApoB, promoting cholesterol clearance. TH can upregulate the expression of LDLR mRNA through binding to thyroid-responsive element (TRE) of LDLR gene on the hepatocyte surface (46). Meanwhile, SREBP2 binds to the sterol regulatory element (SRE) on the LDLR promoter, thereby promoting the transcription of the LDLR gene (47). Therefore, the number of LDLR and LDL-C clearance rates decreased in hypothyroidism. The combined impact of $\mathrm{TH}$ on cholesterol production

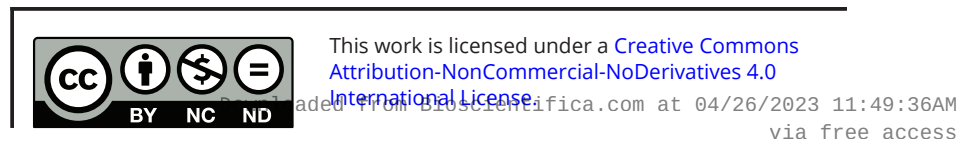




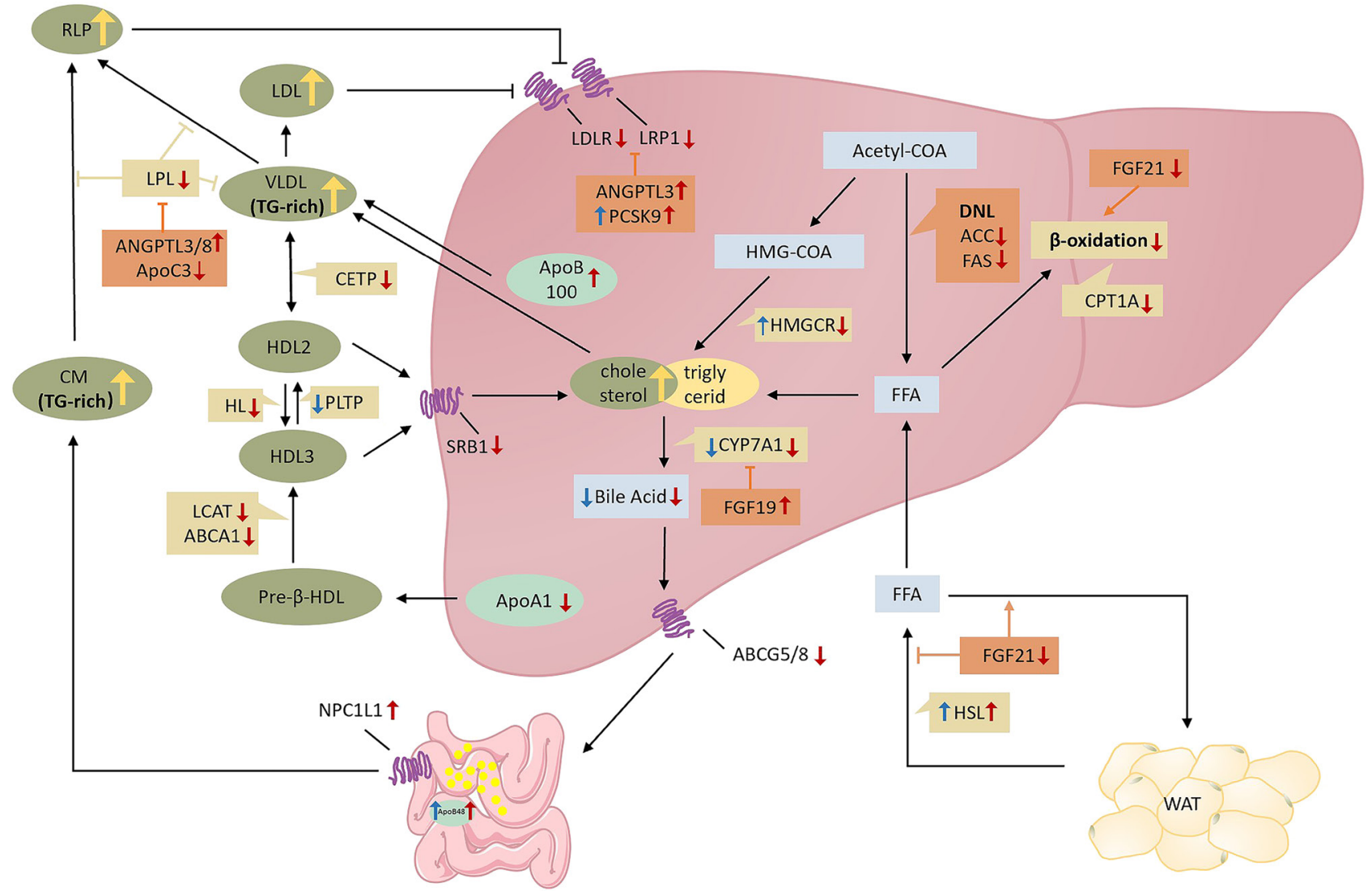

\section{Figure 1}

Effect of decreased TH and increased TSH on lipid metabolism in hypothyroidism. The altered functions are labeled in the presence of hypothyroidism. Red arrows mark actions of declined TH, and blue arrows mark actions of elevated TSH. TH decreases in hypothyroidism and then de novo lipogenesis (DNL) and the activity of HMG-COA reductase (HMGCR) reduce, leading to declined cholesterol production, but free fatty acid (FFA) $\beta$-oxidation also decreases. TH reduction reduces the activity of cholesterol $7 \alpha$-hydroxylase (CYP7A1) and ATP-binding cassette transporter G5/8 (ABCG5/8) to reduce cholesterol clearance. In general, triglyceride (TG)-rich very low-density lipoprotein (VLDL) level is increased in hypothyroidism, and the elevation of Niemann-Pick C1-like 1 protein (NPC1L1) concentration leads to an increase of TG-rich chylomicron (CM). The decrease of TH causes the declined function that lipoprotein lipase (LPL) hydrolyzes CM and VLDL, and the clearance of LDL and remnant lipoprotein (RLP) by LDL receptor (LDLR) and LDL receptor-related protein 1 (LRP1) decreases too, so TG level increases. However, the net concentration of HDL is not consistent. TSH mainly results in the increase of proprotein convertase subtilisin/kexin type 9 (PCSK9), HMGCR and hormone-sensitive lipase (HSL) levels and the decrease of CYP7A1. RLP, remnant lipoprotein; ANGPTL3/8, angiogenin-like protein3/8; ApoC3, apolipoprotein C3; CETP, cholesterol transport protein transporter; HL, hepatic lipase; PLTP, phospholipid transfer protein; LCAT, lecithin cholesterol acyltransferase; ABCA1, ATP-binding cassette transporter A1; SRB1, scavenger receptor b1; FGF19/21, fibroblast growth factors 19/21; HMG-COA, 3-hydroxy-3-methyl glutaryl coenzyme A; ACC, acetyl-CoA carboxylase; FAS, fatty acid synthase; CPT1A, carnitine palmitoyltransferase I $\alpha$; WAT, white adipose tissue.

and clearance leads to a net accumulation of serum LDL-C in hypothyroidism.

On the one hand, TSH can directly affect cholesterol synthesis. Mice with liver TSHR knockout had low TC levels, especially serum LDL-C (48). The binding of TSH to TSHR of hepatocyte membrane upregulates the expression and activity of HMGCR through the cAMP/PKA/CREB signaling pathway (49). TSH can also stimulate the expression of SREBP2 to regulate HMGCR $(35,50)$. In adipocytes, TSH $\beta$ elevates HMGCR mRNA levels, and TSH $\beta$ expression levels in mice's s.c. adipocytes are directly related to circulating cholesterol levels (51). $\mathrm{TSH} \beta$ gene expression is also positively correlated with the expression of fatty acid mobilization (CAV1, ENGL1) (52). It has been found that TSH increased the phosphorylation of perilipin and hormone-sensitive lipase (HSL) to increase lipolysis, and circulating FFA increased significantly after TSH injection in vitro studies (53). Also, TSH could stimulate the increase of $\mathrm{ApoB}(31,45)$. So, we could speculate that TSH is capable as a stand-alone hormone to produce a physiological response on lipid metabolism and have an effect independent of TH.

On the other hand, TSH plays an important part in LDL clearance. TSH induces PI3K/AKT/SREBP2 and SREBP2/HNF4/ Cholesterol $7 \alpha$-hydroxylase (CYP7A1) signaling pathways to inhibit the synthesis of hepatic bile 
acids through TSHR (54). In patients with hypothyroidism and hypercholesterolemia, serum TSH was significantly negatively correlated with bile acid levels, independent of TH (10). Interestingly, the association between TSH and total serum bile acid was stronger in patients under 65 (55).

The decrease of $\mathrm{TH}$ and increase of TSH share similar pathogenic mechanisms of LDL-C accumulation in hypothyroidism, both of which could induce the cholesterol production and inhibit clearance. The effect of TH and TSH on LDL-C in hypothyroidism has been outlined in Fig. 2.

\section{Factors involved in hypothyroidism-related LDL-C elevation}

Fatty acids are obtained from the diet or de novo lipogenesis (DNL), where acetyl-CoA carboxylase (ACC) and fatty acid synthase (FAS) play catalytic roles in the liver and adipose tissue (AT). TH regulates the expression of target genes in two different ways: TH could directly upregulate ACC/FAS through TRE (the direct mechanism) (56) or SREBP1/carbohydrate response element-binding protein
(ChREBP) (the indirect mechanism). The transcription of SREBP1 is negatively regulated via TRE $(56,57)$, but TH can also improve the translation efficiency of SREBP1 mRNA through non-genomic actions (58). Then SREBP1 combines with SRE in ACC and FAS genes to stimulate the expression $(59,60)$. Meanwhile, the inhibition of SREBP1C expression downregulates the expression of HSL gene, thus inhibiting lipid lipolysis (56). It is known that TH $\beta$ influences the expression of ChREBP in hepatocytes (61) and ACC/FAS genes are positively regulated by ChREBP (62). ChREBP and SREBP1C can regulate each other to some extent (63). These new observations suggest that $\mathrm{TH}$ fine-tunes lipid adipogenesis by regulating the expression of SREBP-1C and ChREBP genes respectively.

FGF21is a member of the FGF superfamily. It is mainly released from hepatocytes and is considered as an important endogenous regulator of glucose-lipid metabolism (64), and endogenous FGF21 is mainly released from hepatocytes. When treated with recombinant FGF21, serum TG, VLDL-C and LDL-C of rodents significantly reduced $(65,66)$. The same situation was observed in the human study: LDL-C and TG were lower and HDL-C was higher in patients using FGF21 analog (67). Chronic treatment with recombinant FGF21 can even reduce

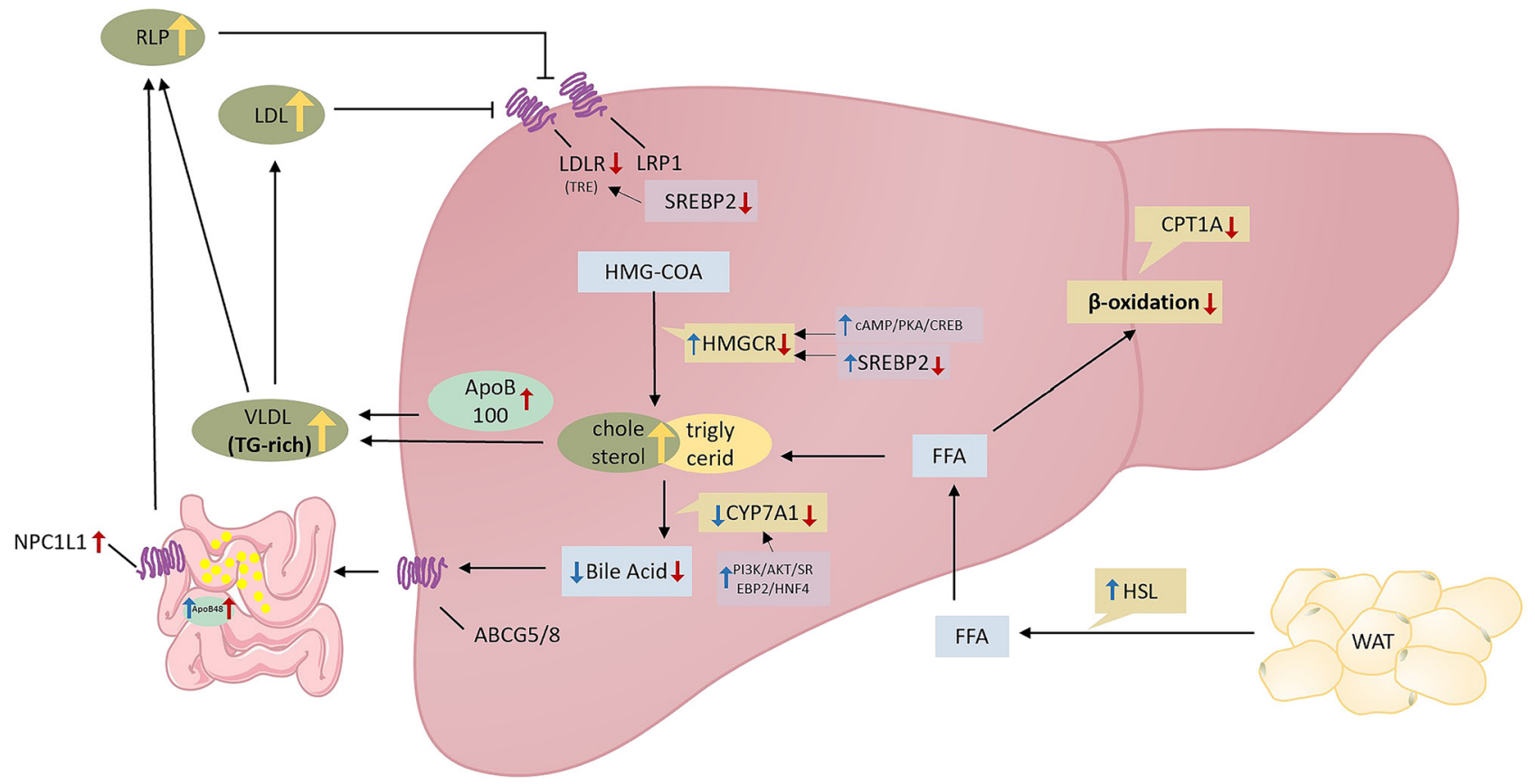

Figure 2

Effect of decreased TH and Increased TSH on LDL-C metabolism in hypothyroidism. The altered functions are labeled in the presence of hypothyroidism. Red arrows mark actions of declined TH, and blue arrows mark actions of elevated TSH. The reduction of TH inhibits cholesterol synthesis via HMGCR, but the absorption of cholesterol through NPC1L1 increases; the catabolism through $\beta$-oxidation and LDL-C clearance through LDL-R decrease. TSH could increase cholesterol synthesis and lipolysis but inhibits the clearance of cholesterol independently. The decrease of TH and increase of TSH induce the net production and inhibit the clearance of LDL-C, thus leading to LDL-C accumulation.

https://ec.bioscientifica.com https://doi.org/10.1530/EC-21-0002 (c) 2022 The authors Published by Bioscientifica Ltd

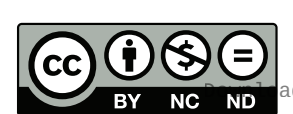

This work is licensed under a Creative Commons Attribution-NonCommercial-NoDerivatives 4.0 International License ifica com at $04 / 26 / 2023$ 11:49:36AM 
serum and liver TG levels in diet-induced obese mice by inhibiting SREBP1 (68). FGF21 reduces circulating FFAs by inhibiting lipolysis in white adipose tissue (WAT) (69) and stimulating FFAs uptake into WAT, consequently decreasing the secretion of VLDL in liver (70). FGF21 could also increase TRL disposal in AT (70).

TH increases FGF21 transcription and peptide levels in mice's liver through THR $\beta$ binding to TRE in FGF21 intron 2 (71). TH also induces liver FGF21 gene expression to promote $\beta$-oxidation by activating AMP-activated protein kinase (AMPK) and Sirtuin 1 (SIRT1) in a proliferatoractivated receptor $\alpha(\mathrm{PPAR} \alpha)$-dependent manner in mice, and the expression of FGF21 reportedly increased in a dosedependent manner in mice treated with exogenous $\mathrm{TH}$ ( 72 , 73). ChREBP also regulates plasma TG levels by regulating FGF21 $(74,75)$. In turn, peripheral administration of FGF21 could decrease TH levels (76).

Studies have found that FGF21 levels were significantly lower in hypothyroidism patients (77) and increased or did not change in hyperthyroidism patients $(78,79)$ due to the effect of TH. However, another study has found that the increase of circulating FGF21 levels in hypothyroidism patients is related to serum TSH (80). So, it could be speculated that TH and TSH have contradictory effects on pathogenetic metabolism. Whether TSH could induce the expression of FGF21 needs further exploration.

FGF19, secreted from the ileum after the stimulation of bile acid (81), participates in the negative feedback regulation of bile acid synthesis by inhibiting liver CYP7A1 (82). TH has a direct effect on the secretion of FGF19 (79). Circulating FGF19 levels significantly decrease in hypothyroidism patients and are independently correlated with TSH levels (83). Further studies have shown that SREBP downregulates the transcription and expression of FGF19 (84).

TH could regulate cholesterol synthesis via miRNA, a kind of small regulatory RNA. TH induces the expression of miR-181d in humans, thereby reducing the expression of caudal type homeobox 2 (CDX2), a transcription factor that activates sterol O-acyl transferase 2 (SOAT2). SOAT2 is essential for converting cholesterol into cholesterol ester (CE), and the latter is the preferred form of LDL (85); and TH mediated the reduction of miR-206, so TG and TC in HepG2 cells declined (86). Also, TH could positively regulate hepatic miR-378, leading to the reduction of serum cholesterol levels through promoting bile acid synthetic pathways (87). Recently, a regulatory module containing three miRNAs (miR-34a-5p, miR-24-3p and miR-130a-3p) and four proteins (thioredoxin, selenium-binding protein
2 , elongation factor $1 \beta$ and prosaposin) about hepatic lipid metabolism was identified in subclinical mice (88).

Proprotein convertase subtilisin/kexin type 9 (PCSK9), a serine protease, binds to the LDLR on the hepatocyte surface, facilitating LDLR degradation in lysosomes and reducing its recycling. PCSK9 could also regulate LDL receptor-related protein 1 (LRP1), which competes with LDLR (89). Studies have shown that TH significantly reduces PCSK9 levels (79). Both SREBP1 and SREBP2 can affect PCSK9 mRNA (90). Studies have found that SREBP2 can bind to the SRE1 site on the PCSK9 promoter (47). The expression of SREBP1C and FAS in liver is involved in circulating PCSK9 and its mRNA levels $(91,92)$. Combined, TH reduces PCSK9 through SREBPs, thereby increasing the expression of LDLR, promoting the clearance of cholesterol in the plasma and reducing cholesterol levels. Currently, studies have found that TSH is significantly positively correlated with plasma PCSK9, which partly depends on SREBP1C, SREBP2 and HMGCR $(93,94)$.

Regulatory factories like ACC/FAS of DNL, FGF21 and miR-181d/206 could affect the synthesis of LDL-C, while factories like FGF19 and PCSK9 influence the degradation of LDL-C. The detailed metabolisms are shown in Fig. 3.

\section{Hypothyroidism and hypertriglyceridemia}

\section{Hypothyroidism affects TG production and transformation}

TG comes from circulating exogenous or intracellular FFAs produced by glycolysis and fat. TH could reduce the production of VLDL-TG in liver (95). When the rate of lipolysis remains unchanged, hypothyroidism will lead to decreased lipid oxidation rates and elevated TG (96). TH could also increase ApoA5 mRNA and protein levels in hepatocytes, leading to a decline of TG (97). TH mainly upregulates the activity of lipoprotein lipase (LPL), which could lead to the lipolysis of TRLs, including CM and VLDL; the decrease of TH leads to the attenuation of these effects, thus promoting the elevation of serum TG in hypothyroidism (98). Studies have shown that impaired hepatic lipase (HL) activity in hypothyroidism patients may also be related to the accumulation of TRL (45). The transfer of TG to HDL is impaired in subclinical hypothyroidism patients (99).

Remnant lipoprotein (RLP) is composed of cholesterol, CE and ApoE-riched smaller particles. TRL particles gradually lose TG, phospholipid, ApoA and ApoC then transfers to RLP after being hydrolyzed by LPL. Existing studies have shown that hypothyroidism is associated with 


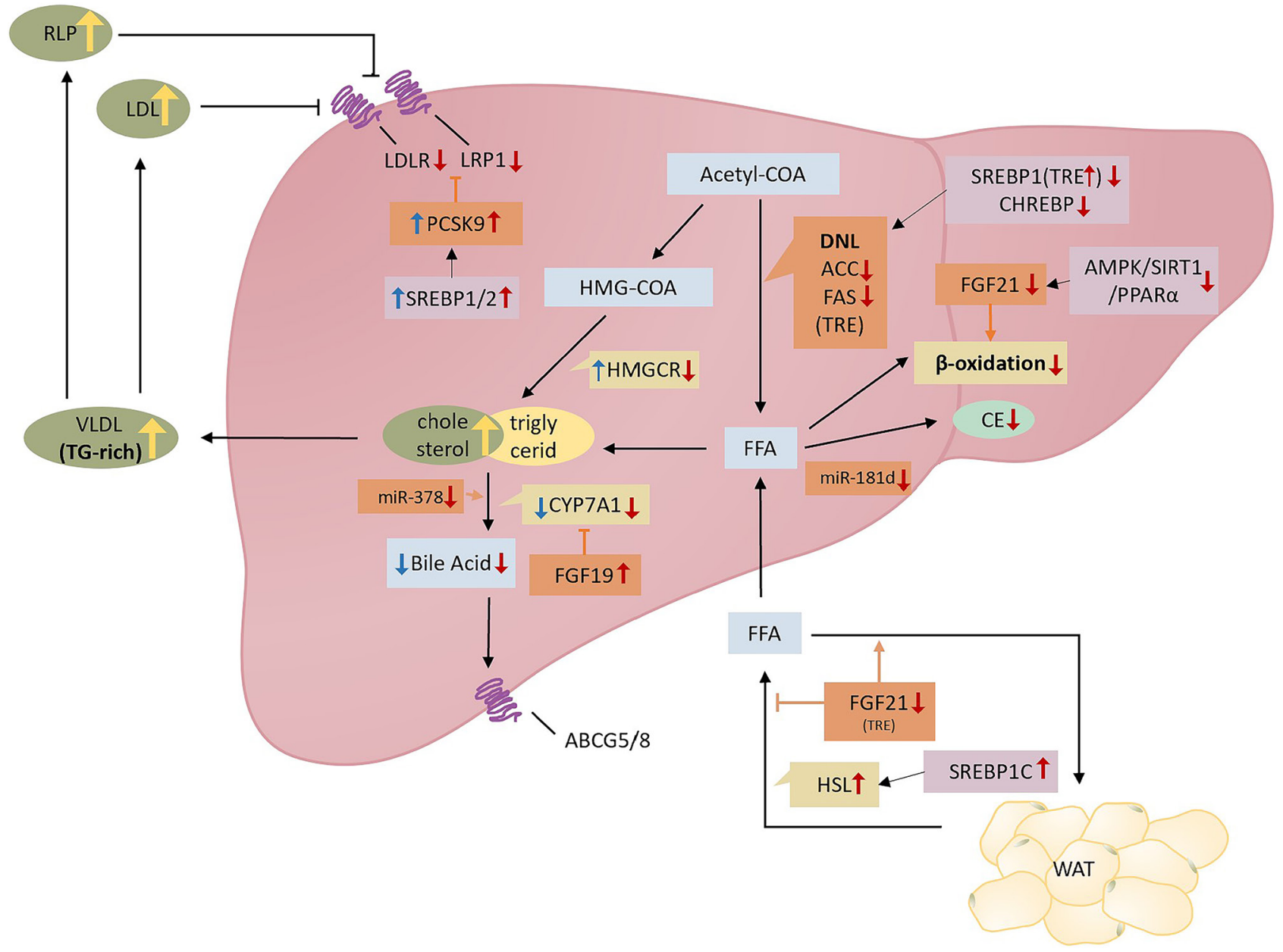

Figure 3

Regulatory factors involved in hypothyroidism-related dyslipidemia. The altered functions are labeled in the presence of hypothyroidism. Red arrows mark actions of declined TH, and blue arrows mark actions of elevated TSH. ACC/FAS, FGF21 and miR-181d/206 could affect the synthesis of LDL-C, while factors like FGF19 and PCSK9 influence the degradation of LDL-C. In hypothyroidism, FFA synthesis via DNL decrease, and the indirect mechanisms of TH on SREBP1 is stronger than the direct mechanisms through TRE. The oxidation and lipolysis of FFA decreases partly because of hypothyroidism-induced decreased FGF-21. FGF-19 inhibits bile acid synthesis and PCSK9 increases the degradation of LDLR, thus inhibiting the clearance of cholesterol in hypothyroidism.

increased serum RLP levels (100). On the one hand, the excess production of TRL particles in the liver can explain the elevated RLP levels in hypothyroidism patients. On the other hand, LRP1 is expressed on the hepatocyte surface and binds to ApoE, internalizing TRL and contributing to RLP clearance. TH influences the lipid profile by increasing the transcription of LRP1 in mice and humans (101). Interestingly, SREBP1 and SREBP2 could downregulate the transcription of LRP1 in human vascular smooth muscle cells and macrophages through binding to SRE $(102,103)$. Therefore, hypothyroidism can lead to LRP1 reduction and RLP clearance through SREBP.

TSH could also promote the synthesis of TG. It binds to TSHR to promote TG synthesis in differentiated adipocytes via AMPK/PPAR $\gamma /$ GPAT3 axis (104). TSH could also significantly increase TG levels in hepatocytes in a dose-dependent manner through TSHR/cAMP/PKA/ PPAR $\alpha$ and PPAR $\alpha / A M P K / S R E B P 1 C$ signaling pathways $(49,105)$. Higher TSH levels in the euthyroid population may affect TG-rich metabolism via ApoE (106), which could explain increased ApoE levels in hypothyroidism patients (107).

\section{Hypothyroidism and newly identified mechanisms factors in TG metabolism}

ANGPTL1-8 are secretory glycoproteins composed of an $\mathrm{N}$-terminal helical domain and a C-terminal fibrinogenlike domain. Angptl3 is identified for proteolysis at positions 221-224 to produce N-terminal domains. 
TH could inhibit mRNA of ANGPTL3 TR $\beta$ dependently (108), and there was a positive correlation between ANGPTL3 and TSH in Graves' disease patients (109). Circulating VLDL-TG and LDL-C declined in ANGPTL3 loss-of-function heterozygotes $(110,111)$ because some studies have shown that ANGPTL3 at high concentration could inhibit LPL $(112,113)$. ANGPTL3 cleaves LPL through furin protease (114) and shows reversible inhibition of LPL catalytic activity. However, other studies also found that ANGPTL3 inactivates LPL by catalyzing the irreversible unfolding of its hydrolase domain, which is similar to ANGPTL4 (115). Furthermore, ANGPTL3 deficiency could lead to declined postprandial lipid levels, possibly due to accelerated catabolic metabolism of TRLs and reduced flow of fatty acids into liver $(116,117)$. One study demonstrated that ANGPTL3 gene siRNAs induced increased expression of LDLR/LRP1 and reduced the secretion of apoB100, resulting in increased uptake of LDL/VLDL (118). However, in another study, it was reported that the use of ANGPTL3 $\mathrm{MAB}$, the reduction of LDL-C could be independent of the LDLR pathway, and it was speculated that the transformation from VLDL to LDL reduced partially because of increased ApoB clearance (111). Circulating ANGPTL3 levels elevated and were positively correlated with HDL-C in hypothyroidism patients (119). ANGPTL 3 acts as an inhibitor of endothelial lipase, which could hydrolyze HDL-phospholipid to reduce plasma HDL levels, and ANGPTL 3 is also involved in promoting the elevation of plasma HDL-C in humans and rodents (120).

ANGPTL8, known as TD26, re-feeding induced in fat and liver, lipasin and betatrophin, is an atypical member of ANGPTL family. It is expressed mainly in liver of humans, while in AT and liver of mice. The TG clearance rate and LPL activity in Angptl8 knockout mice increase significantly, thus reducing the plasma TG levels $(121,122)$. ANGPTL8 can cooperate with ANGPTL3 to improve the binding of ANGPTL3 to LPL and promote LPL lysis to increase the plasma TG level in mice $(123,124,125)$. ANGPTL3 and ANGPTL8 can even promote each other somehow (125). Circulating Angptl8 levels increase in hypothyroidism patients and positively correlate with TSH, TG and TC (119, $122,126,127,128)$. However, ANGPTL8 mRNA in HepG2 cells is induced by TH (129), and its expression can also be specifically activated in the liver of mice through SREBP1a and SREBP2 (124). These pieces of evidence could suggest that TH and TSH regulate ANGPTL8. TH could also convert lipid droplets through the autophagy process activated by ANGPTL8 to regulate lipid metabolism (129). In addition, the lipid contents in adipocytes significantly reduced after the deletion of ANGPTL8 gene (130). ANGPTL8 protein levels are positively related to TC, LDL-C in patients with morbid obesity and type 2 diabetes (131), but whether it is related to hypothyroidism or not, the answer remains uncertain.

ANGPTL6, also known as AGF, does not bind to angiogenin receptors. In patients with hypothyroidism, serum ANGPTL6 levels increase and are positively correlated with TSH and TC (132). Serum ANGPTL6 levels are also an independent predictor of low HDL and high TG (133). Studies have found that ANGPTL6 could mediate increased expression of PPAR $\alpha$ through the extracellular regulated protein kinases/mitogen-activated protein kinase (ERK/MAPK) signaling pathway, leading to increased expression of FGF21, thereby promoting $\beta$-oxidation (134). It is possible to predict that TSH could induce FGF21 through ANGPTL6; however, TH has the opposite effect on FGF21 from TSH and the effect prevails, so serum FGF21 level is more prone to decrease in hypothyroidism as mentioned above.

The domain of Angptl4 is similar to Angptl3 (135). But, TH could not inhibit the expression of Angptl4 mRNA (108), and there is no significant change of Angptl4 levels in hypothyroidism (119). So, we could speculate that TH could not influence lipid metabolism through Angptl4.

Serum ApoC3, another LPL inhibitor, was found to decrease in hypothyroidism mice with or without pregnancy (42). The suppressed expression of ApoC3 gene leads to increased LPL activity and decreased plasma TG levels (136). Taken together, ApoC3 decrease leads to LPL increase in the presence of hypothyroidism.

Angpt13/6/8 and ApoC3 play important roles in TG transformation, especially Angptl3 and Angptl8 make a synergic reaction. More basic and epidemiological studies are needed to verify the deeper relationship between Angptl6/FGF21 and TSH. The detailed effects of TH and TSH on TG metabolisms are shown in Fig. 4.

\section{Hypothyroidism and HDL-C metabolism}

\section{Thyroid hormone affects HDL levels}

HDL synthesis decreases in hypothyroidism. A study has documented a positive relationship between FT4 and plasma pre- $\beta$-HDL formation in type 2 diabetes mellitus patients (137). TH strongly induces ApoA1 gene and protein expression (138), thereby increasing cholesterol efflux from peripheral tissues to HDL in reverse cholesterol transport (RCT). Homocysteine levels significantly increase in hypothyroidism mice; and homocysteine can reduce circulating HDL-C by inhibiting ApoA1 protein synthesis, thereby inhibiting RCT (139). However, ApoA1 levels 


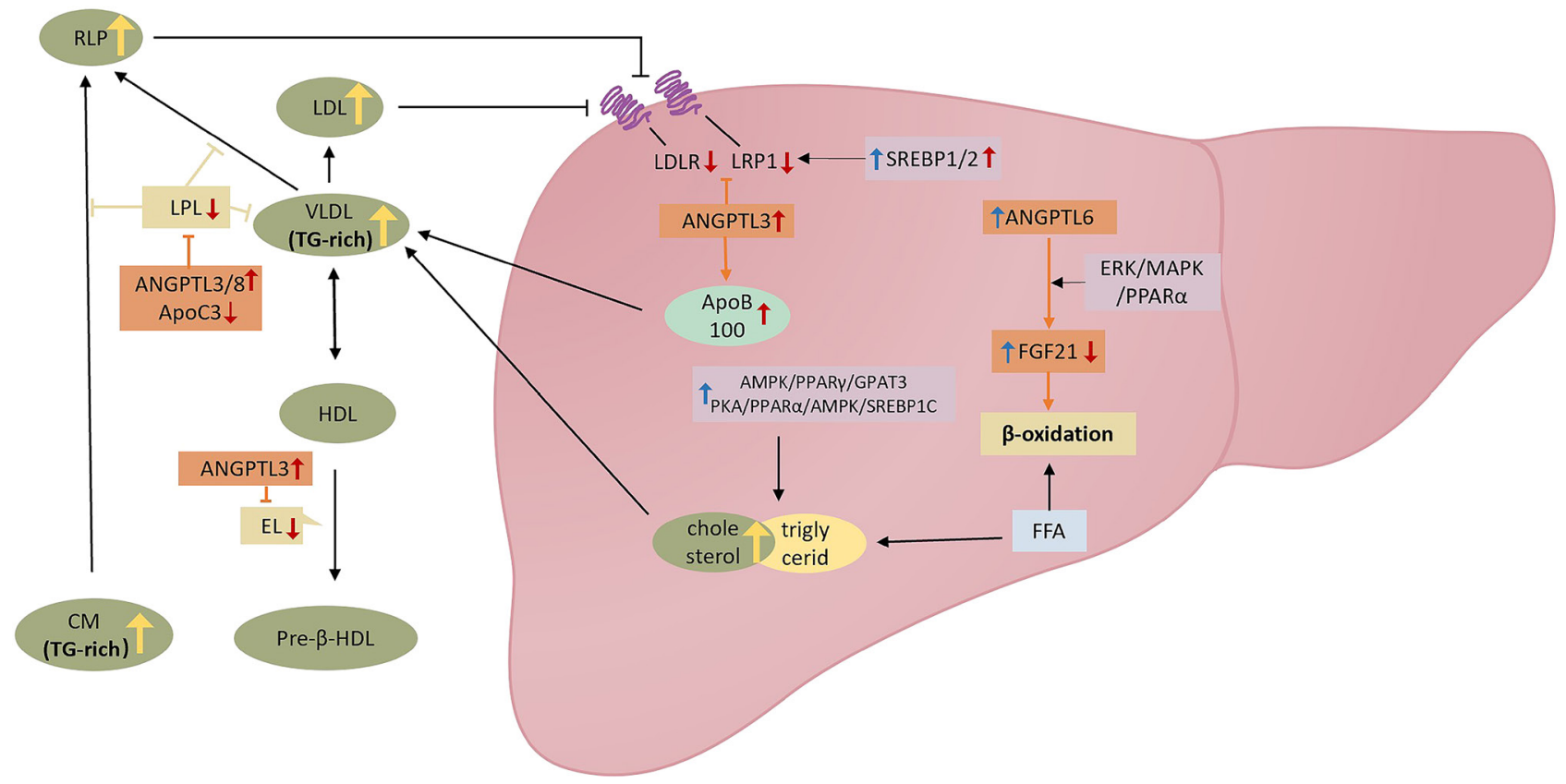

Figure 4

Effect of decreased TH and increased TSH on TG metabolism in hypothyroidism. The altered functions are labeled in the presence of hypothyroidism. Red arrows mark actions of declined TH, and blue arrows mark actions of elevated TSH. The increase of Angptl3 in hypothyroidism could inhibit LDL degradation via LDL-R and inhibit cholesterol transport via LPL and EL. TSH is related to Angpt|6, influencing $\beta$-oxidation to some extent.

increase in hypothyroidism patients after thyroidectomy $(140,141)$. The potential causes of the contradictory result are not clear yet. TH could also stimulate cholesterol efflux from macrophages to HDL via transporter protein ATP-binding cassette transporter A1 (ABCA1) (138). The activity of ABCA1 and lecithin cholesterol acyltransferase decreases in hypothyroidism, which leads to the inhibition of the synthesis and maturation process of HDL particles (142).

The HDLclearance and transformation process decrease in hypothyroidism. TH stimulates HL, thus promoting HDL degradation and changing HDL components (143). Plasma cholesterol transport protein transporter (CETP) concentrations decrease in hypothyroidism, resulting in elevated plasma HDL-C levels (144). TH can increase the transcription of CYP7A1, a rate-limiting enzyme in RCT, thus promoting the transformation of cholesterol into bile acid (145). TH could also stimulate the secretion of bile acid in liver and intestine by stimulating the transcription of ATP-binding cassette transporter G5/8 (ABCG5/ ABCG8) in rats (138), which is the last step of RCT (146). Hypothyroidism could inhibit cholesterol clearance by decreasing scavenger receptor b1 (147). These effects of TH on HDL synthesis and clearance counteract each other; therefore, the HDL-C level is not constant.
Patients with a moderate increase in TSH had reduced CETP and phospholipid transfer protein activities, which resulted in decreased HDL2 and elevated HDL3 levels (148). However, in T2DM patients, there is a positive correlation between TSH and CETP, thereby raising the possibility that hyperglycemia has strong effects on the ability of VLDL to accept cholesteryl esters from HDL (149). Hence, HDL-C levels could be affected by numerous conditions. The detailed effects of TH and TSH on HDL levels are shown in Fig. 5.

\section{Hypothyroidism impairs HDL cholesterol efflux capacity}

Though HDL levels were not consistent, cholesterol efflux capacity (CEC) was impaired in overt hypothyroidism, reflecting HDL function losses (107, 141). Paraoxonase-1 (PON1) is an important anti-oxidative enzyme that resides on HDL. Recent reports showed that after thyroidectomy, PON1 activity remained unaltered (140) but the PON1/ApoA1 ratio decreased (107). Altogether, hypothyroidism may affect HDL function through several unclear mechanisms.

Even though elevated HDL-C levels could not always protect humans from CVD and mortality, CEC is a 


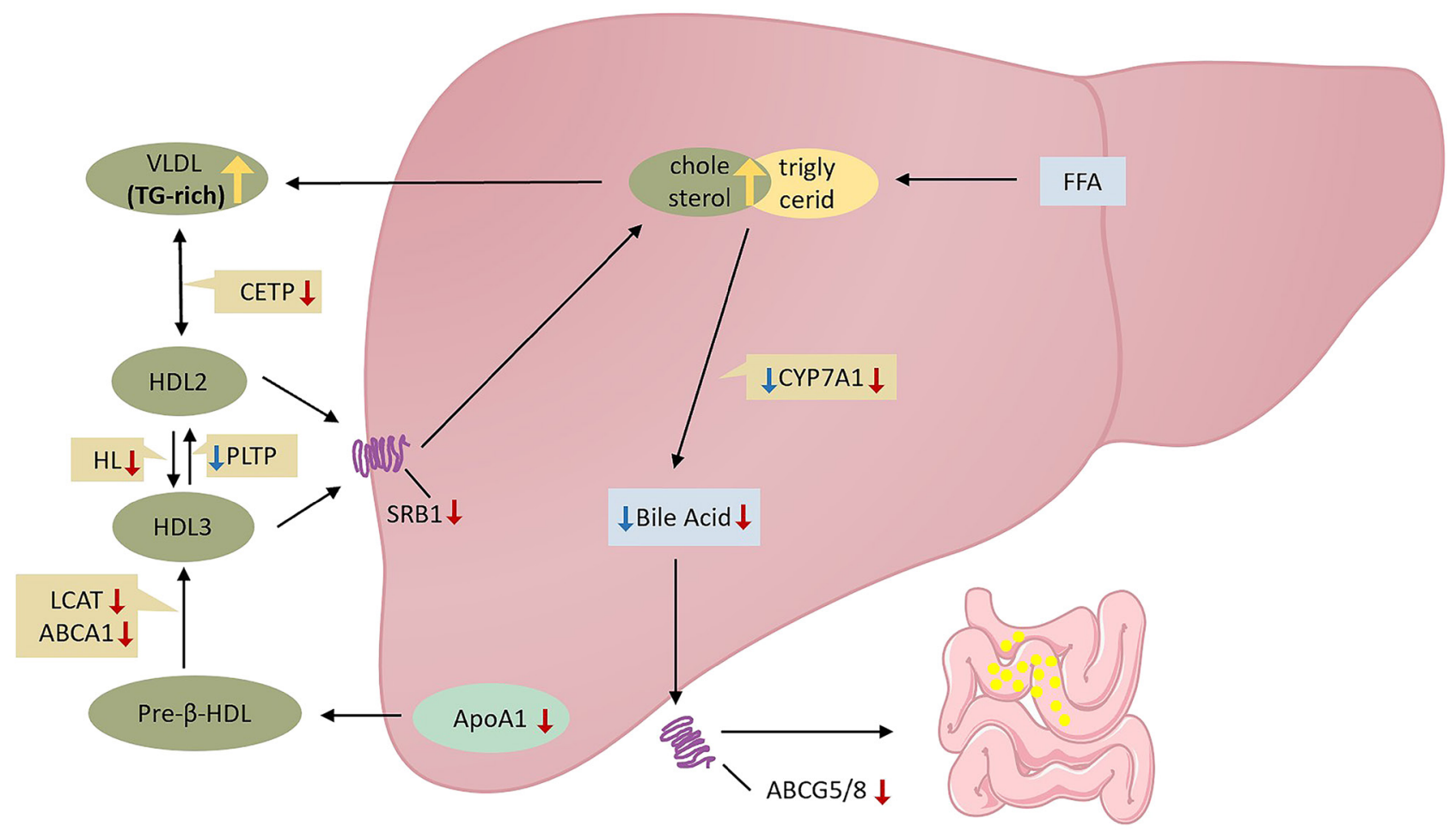

Figure 5

Effect of decreased TH and increased TSH on HDL metabolism in hypothyroidism. The altered functions are labeled in the presence of hypothyroidism. Red arrows mark actions of declined TH, and blue arrows mark actions of elevated TSH. HDL synthesis via LCAT, ABVA1 and apoA1 enhances but HDL clearance and transformation process decreases in hypothyroidism because of TH-induced decreased HL, CEPT, CYP7A1, ABCG5/8 and SR-B1. Several effects counteract each other; therefore, the HDL-C level is not constant.

biomarker of HDL functionality and is cardioprotective. So what we should pay more attention to is HDL CEC (150).

\section{Conclusion}

Besides known TH metabolic pathways, TSH is also shown to be an important factor influencing lipid metabolism in vitro and in vivo. Either the decrease of TH or the increase of TSH in hypothyroidism could increase LDL-C and TG. HDL levels are not constant because regulating factors counteract each other; however, HDL function, a predictor of cardiovascular risk independent of HDL-C levels, is impaired in hypothyroidism. Hence, we could focus on the mechanism of how THaffects HDL function. Even in normal thyroid and subclinical hypothyroidism, higher TSH levels could affect lipid metabolism through an independent TSH signaling pathway. It seems that keeping TSH at a low normal level to minimize cholesterol concentrations is an important treatment in hypothyroidism from a clinical point of view. Significantly, the main hormone physiological change of hypothyroidism patients comes from $\mathrm{TH}$; and $\mathrm{TSH}$ could be influenced by $\mathrm{TH}$ negative feedback regulation. Combined, whether TSH metabolic pathway makes up a large proportion of hypothyroidism or not, we need more evidence to figure it out.

Currently, we find that many regulatory factors, like SREBPs, ChREBP, ANGPTLs and FGF19/21, are also involved in lipid metabolism of hypothyroidism. These factors provide potential drug targets for treatments of hypothyroidism-related hyperlipidemia, like Angptl3 inhibitor, Evinacumab. However, the specific mechanism of TH or TSH on some factors has not been clarified yet. For instance, whether TSH could influence cholesterol metabolism through Angptl6 and FGF19 pathways is unclear. So, further basic and epidemiological studies are required to clarify the contradictory change of lipid levels and mechanism of these newly identified factors.

\section{Declaration of interest}

The authors declare that there is no conflict of interest that could be perceived as prejudicing the impartiality of this review.
This work is licensed under a Creative Commons Attribution-NonCommercial-NoDerivatives 4.0 international License ifica com at $04 / 26 / 2023$ 11:49:36 Am 


\section{Funding}

This project was supported by grants from National Natural Science Foundation of China (No. 81870336 to D Q P).

\section{Author contribution statement}

$\mathrm{H} X \mathrm{X}$ and $\mathrm{D} \mathrm{Q} \mathrm{P}$ contributed to the study design; $\mathrm{H} X \mathrm{~L}$ wrote the manuscript. All authors reviewed drafts and approved the final version of the manuscript.

\section{References}

1 Chen Y, Wu X, Wu R, Sun X, Yang B, Wang Y \& Xu Y. Changes in profile of lipids and adipokines in patients with newly diagnosed hypothyroidism and hyperthyroidism. Scientific Reports 2016626174. (https://doi.org/10.1038/srep26174)

2 Writing Group Members, Mozaffarian D, Benjamin EJ, Go AS, Arnett DK, Blaha MJ, Cushman M, Das SR, de Ferranti S, Després JP, et al. Heart disease and stroke statistics-2016 update: a report from the American Heart Association. Circulation 2016133 e38-e360. (https:// doi.org/10.1161/CIR.0000000000000350)

3 Abdel-Gayoum AA. Dyslipidemia and serum mineral profiles in patients with thyroid disorders. Saudi Medical Journal 201435 1469-1476.

4 Zhao M, Liu L, Wang F, Yuan Z, Zhang X, Xu C, Song Y, Guan Q, Gao L, Shan Z, et al. A worthy finding: decrease in total cholesterol and low-density lipoprotein cholesterol in treated mild subclinical hypothyroidism. Thyroid 201626 1019-1029. (https://doi.org/10.1089/ thy.2016.0010)

5 Scherer T, Wolf P, Winhofer Y, Duan H, Einwallner E, Gessl A, Luger A, Trattnig S, Hoffmann M, Niessner A, et al. Levothyroxine replacement in hypothyroid humans reduces myocardial lipid load and improves cardiac function. Journal of Clinical Endocrinology and Metabolism 201499 E2341-E2346. (https://doi.org/10.1210/jc.20142112)

6 Arinzon Z, Zuta A, Peisakh A, Feldman J \& Berner Y. Evaluation response and effectiveness of thyroid hormone replacement treatment on lipid profile and function in elderly patients with subclinical hypothyroidism. Archives of Gerontology and Geriatrics 2007 44 13-19. (https://doi.org/10.1016/j.archger.2006.01.006)

7 Tagami T, Kimura H, Ohtani S, Tanaka T, Tanaka T, Hata S, Saito M, Miyazaki Y, Araki R, Tanaka M, et al. Multi-center study on the prevalence of hypothyroidism in patients with hypercholesterolemia. Endocrine Journal 201158 449-457. (https://doi.org/10.1507/endocrj. k11e-012)

8 Willard DL, Leung AM \& Pearce EN. Thyroid function testing in patients with newly diagnosed hyperlipidemia. JAMA Internal Medicine 2014174 287-289. (https://doi.org/10.1001/ jamainternmed.2013.12188)

9 Bekkering GE, Agoritsas T, Lytvyn L, Heen AF, Feller M, Moutzouri E, Abdulazeem H, Aertgeerts B, Beecher D, Brito JP, et al. Thyroid hormones treatment for subclinical hypothyroidism: a clinical practice guideline. BMJ 2019365 12006. (https://doi.org/10.1136/bmj. 12006)

10 Song Y, Zhao M, Zhang H, Zhang X, Zhao J, Xu J \& Gao L. Thyroidstimulating hormone levels are inversely associated with serum total bile acid levels: a cross-sectional study. Endocrine Practice 201622 420-426. (https://doi.org/10.4158/EP15844.OR)

11 Alsamghan AS, Alsaleem SA, Alzahrani MAS, Patel A, Mallick AK $\&$ Sheweita SA. Effect of hypovitaminosis D on lipid profile in hypothyroid patients in Saudi Arabia. Oxidative Medicine and Cellular Longevity 20202020 6640402. (https://doi.org/10.1155/2020/6640402)
12 Heima NE, Eekhoff EMW, Oosterwerff MM, Lips PTA, van Schoor NM $\&$ Simsek S. Thyroid function and the metabolic syndrome in older persons: a population-based study. European Journal of Endocrinology 2013 168 59-65. (https://doi.org/10.1530/EJE-12-0375)

13 Cerbone M, Capalbo D, Wasniewska M, Alfano S, Mattace Raso G, Oliviero U, Cittadini A, De Luca F \& Salerno M. Effects of L-thyroxine treatment on early markers of atherosclerotic disease in children with subclinical hypothyroidism. European Journal of Endocrinology 2016 175 11-19. (https://doi.org/10.1530/EJE-15-0833)

14 Liu FH, Hwang JS, Kuo CF, Ko YS, Chen ST \& Lin JD. Subclinical hypothyroidism and metabolic risk factors association: a health examination-based study in northern Taiwan. Biomedical Journal 2018 41 52-58. (https://doi.org/10.1016/j.bj.2018.02.002)

15 Unal E, Akın A, Yıldırım R, Demir V, Yildiz İ \& Haspolat YK. Association of subclinical hypothyroidism with dyslipidemia and increased carotid intima-media thickness in children. Journal of Clinical Research in Pediatric Endocrinology 2017 9 144-149. (https://doi. org/10.4274/jcrpe.3719)

16 Arikan S, Bahceci M, Tuzcu A, Celik F \& Gokalp D. Postprandial hyperlipidemia in overt and subclinical hypothyroidism. European Journal of Internal Medicine 201223 e141-e145. (https://doi. org/10.1016/j.ejim.2012.05.007)

17 Martin SS, Daya N, Lutsey PL, Matsushita K, Fretz A, McEvoy JW, Blumenthal RS, Coresh J, Greenland P, Kottgen A, et al. Thyroid function, cardiovascular risk factors, and incident atherosclerotic cardiovascular disease: the atherosclerosis risk in communities (ARIC) study. Journal of Clinical Endocrinology and Metabolism 2017102 3306-3315. (https://doi.org/10.1210/jc.2017-00986)

18 van Vliet NA, Bos MM, Thesing CS, Chaker L, Pietzner M, Houtman E, Neville MJ, Li-Gao R, Trompet S, Mustafa R, et al. Higher thyrotropin leads to unfavorable lipid profile and somewhat higher cardiovascular disease risk: evidence from multi-cohort Mendelian randomization and metabolomic profiling. BMC Medicine 202119 266. (https://doi. org/10.1186/s12916-021-02130-1)

19 Yuan C, Sun X, Liu Y \& Wu J. The thyroid hormone levels and glucose and lipid metabolism in children with type 1 diabetes: a correlation analysis. Translational Pediatrics 202110 276-282. (https://doi. org/10.21037/tp-20-204)

20 Iqbal AM, Lteif AN \& Kumar S. Association between mild hyperthyrotropinemia and hypercholesterolemia in children with severe obesity. Journal of Pediatric Endocrinology and Metabolism 201932 561-568. (https://doi.org/10.1515/jpem-2018-0519)

21 Dahl AR, Iqbal AM, Lteif AN, Pittock ST, Tebben PJ \& Kumar S. Mild subclinical hypothyroidism is associated with paediatric dyslipidaemia. Clinical Endocrinology 201889 330-335. (https://doi. org/10.1111/cen.13752)

22 Jin HY. Prevalence of subclinical hypothyroidism in obese children or adolescents and association between thyroid hormone and the components of metabolic syndrome. Journal of Paediatrics and Child Health 201854 975-980. (https://doi.org/10.1111/jpc.13926)

23 Jain RB. Associations between the levels of thyroid hormones and lipid/lipoprotein levels: data from National Health and Nutrition Examination Survey 2007-2012. Environmental Toxicology and Pharmacology 201753 133-144. (https://doi.org/10.1016/j. etap.2017.05.002)

24 Luxia L, Jingfang L, Songbo F, Xulei T, Lihua M, Weiming S, Ying N, Gaojing J, Qianglong N, Yujuan L, et al. Correlation between serum TSH levels within normal range and serum lipid profile. Hormone and Metabolic Research 202053 32-40. (https://doi. org/10.1055/a-1191-7953)

25 Kuś A, Marouli E, Del Greco FM, Chaker L, Bednarczuk T, Peeters RP, Teumer A, Medici M \& Deloukas P. Variation in normal range thyroid function affects serum cholesterol levels, blood pressure, and type 2 diabetes risk: a mendelian randomization study. Thyroid 202131 721-731. (https://doi.org/10.1089/thy.2020.0393) https://ec.bioscientifica.com https://doi.org/10.1530/EC-21-0002 (c) 2022 The authors Published by Bioscientifica Ltd
This work is licensed under a Creative Commons Attribution-NonCommercial-NoDerivatives 4.0 International License.ifica com at $04 / 26 / 2023$ 11:49:36 AM 
26 Chang YC, Hua SC, Chang CH, Kao WY, Lee HL, Chuang LM, Huang YT \& Lai MS. High TSH level within normal range is associated with obesity, dyslipidemia, hypertension, inflammation, hypercoagulability, and the metabolic syndrome: a novel cardiometabolic marker. Journal of Clinical Medicine 20198817. (https://doi.org/10.3390/jcm8060817)

27 Ahi S, Amouzegar A, Gharibzadeh S, Delshad H, Tohidi M \& Azizi F. Trend of lipid and thyroid function tests in adults without overt thyroid diseases: a cohort from Tehran thyroid study. PLOS ONE 2019 14 e0216389. (https://doi.org/10.1371/journal.pone.0216389)

28 Chamba A, Neuberger J, Strain A, Hopkins J, Sheppard MC \& Franklyn JA. Expression and function of thyroid hormone receptor variants in normal and chronically diseased human liver. Journal of Clinical Endocrinology and Metabolism 199681 360-367. (https://doi. org/10.1210/jcem.81.1.8550778)

29 Wang F, Tan Y, Wang C, Zhang X, Zhao Y, Song X, Zhang B, Guan Q, $\mathrm{Xu}$ J, Zhang J, et al. Thyroid-stimulating hormone levels within the reference range are associated with serum lipid profiles independent of thyroid hormones. Journal of Clinical Endocrinology and Metabolism 201297 2724-2731. (https://doi.org/10.1210/jc.2012-1133)

30 Geng H, Zhang X, Wang C, Zhao M, Yu C, Zhang B, Wang Y, Ban B \& Zhao J. Even mildly elevated TSH is associated with an atherogenic lipid profile in postmenopausal women with subclinical hypothyroidism. Endocrine Research 201540 1-7. (https://doi.org/10.31 09/07435800.2013.879166)

31 Beukhof CM, Massolt ET, Visser TJ, Korevaar TIM, Medici M, de Herder WW, Roeters van Lennep JE, Mulder MT, de Rijke YB, Reiners C, et al. Effects of thyrotropin on peripheral thyroid hormone metabolism and serum lipids. Thyroid 201828 168-174. (https://doi. org/10.1089/thy.2017.0330)

32 Xu C, Yang X, Liu W, Yuan H, Yu C, Gao L \& Zhao J. Thyroid stimulating hormone, independent of thyroid hormone, can elevate the serum total cholesterol level in patients with coronary heart disease: a cross-sectional design. Nutrition and Metabolism 2012944. (https://doi.org/10.1186/1743-7075-9-44)

33 Zhang W, Tian LM, Han Y, Ma HY, Wang LC, Guo J, Gao L \& Zhao JJ. Presence of thyrotropin receptor in hepatocytes: not a case of illegitimate transcription. Journal of Cellular and Molecular Medicine 200913 4636-4642. (https://doi.org/10.1111/j.15824934.2008.00670.x)

34 Santini F, Galli G, Maffei M, Fierabracci P, Pelosini C, Marsili A, Giannetti M, Castagna MG, Checchi S, Molinaro E, et al. Acute exogenous TSH administration stimulates leptin secretion in vivo. European Journal of Endocrinology 2010163 63-67. (https://doi. org/10.1530/EJE-10-0138)

35 Zhang X, Song Y, Feng M, Zhou X, Lu Y, Gao L, Yu C, Jiang X \& Zhao J. Thyroid-stimulating hormone decreases HMG-CoA reductase phosphorylation via AMP-activated protein kinase in the liver. Journal of Lipid Research 201556 963-971. (https://doi.org/10.1194/jlr. M047654)

36 Choi JW \& Choi HS. The regulatory effects of thyroid hormone on the activity of 3-hydroxy-3-methylglutaryl coenzyme A reductase. Endocrine Research 200026 1-21. (https://doi. org/10.1080/07435800009040142)

37 Shin DJ \& Osborne TF. Thyroid hormone regulation and cholesterol metabolism are connected through sterol regulatory elementbinding protein-2 (SREBP-2). Journal of Biological Chemistry 2003278 34114-34118. (https://doi.org/10.1074/jbc.M305417200)

38 Gälman C, Bonde Y, Matasconi M, Angelin B \& Rudling M. Dramatically increased intestinal absorption of cholesterol following hypophysectomy is normalized by thyroid hormone. Gastroenterology 2008134 1127-1136. (https://doi.org/10.1053/j.gastro.2008.01.032)

39 Sinha RA, You SH, Zhou J, Siddique MM, Bay BH, Zhu X, Privalsky ML, Cheng SY, Stevens RD, Summers SA, et al. Thyroid hormone stimulates hepatic lipid catabolism via activation of autophagy. Journal of
Clinical Investigation 2012122 2428-2438. (https://doi.org/10.1172/ JCI60580)

40 McGarry JD \& Brown NF. The mitochondrial carnitine palmitoyltransferase system. From concept to molecular analysis. European Journal of Biochemistry 1997244 1-14. (https://doi. org/10.1111/j.1432-1033.1997.00001.x)

41 Jackson-Hayes L, Song S, Lavrentyev EN, Jansen MS, Hillgartner FB, Tian L, Wood PA, Cook GA \& Park EA. A thyroid hormone response unit formed between the promoter and first intron of the carnitine palmitoyltransferase-Ialpha gene mediates the liver-specific induction by thyroid hormone. Journal of Biological Chemistry 2003278 7964-7972. (https://doi.org/10.1074/jbc.M211062200)

42 Zhou J, Dong X, Liu Y, Jia Y, Wang Y, Zhou J, Jiang Z \& Chen K. Gestational hypothyroidism elicits more pronounced lipid dysregulation in mice than pre-pregnant hypothyroidism. Endocrine Journal 202067 593-605. (https://doi.org/10.1507/endocrj.EJ19-0455)

43 Goldberg IJ, Huang LS, Huggins LA, Yu S, Nagareddy PR, Scanlan TS \& Ehrenkranz JR. Thyroid hormone reduces cholesterol via a nonLDL receptor-mediated pathway. Endocrinology 2012153 5143-5149. (https://doi.org/10.1210/en.2012-1572)

44 Davidson NO, Powell LM, Wallis SC \& Scott J. Thyroid hormone modulates the introduction of a stop codon in rat liver apolipoprotein B messenger RNA. Journal of Biological Chemistry 1988263 13482-13485. (https://doi.org/10.1016/S0021-9258(18)68263-8)

45 Mugii S, Hanada H, Okubo M, Masuda D, Takeoka K, Hidaka Y, Ohama T, Matsuyama A, Nakagawa-Toyama Y, Nishida M, et al. Thyroid function influences serum apolipoprotein B-48 levels in patients with thyroid disease. Journal of Atherosclerosis and Thrombosis 201219 890-896. (https://doi.org/10.5551/jat.12757)

46 Lopez D, Abisambra Socarrás JF, Bedi M \& Ness GC. Activation of the hepatic LDL receptor promoter by thyroid hormone. Biochimica et Biophysica Acta 20071771 1216-1225. (https://doi.org/10.1016/j. bbalip.2007.05.001)

47 Dong B, Singh AB, Fung C, Kan K \& Liu J. CETP inhibitors downregulate hepatic LDL receptor and PCSK9 expression in vitro and in vivo through a SREBP2 dependent mechanism. Atherosclerosis 2014 235 449-462. (https://doi.org/10.1016/j.atherosclerosis.2014.05.931)

48 Zhou L, Wu K, Zhang L, Gao L \& Chen S. Liver-specific deletion of TSHR inhibits hepatic lipid accumulation in mice. Biochemical and Biophysical Research Communications 2018497 39-45. (https://doi. org/10.1016/j.bbrc.2018.01.187)

49 Tian L, Song Y, Xing M, Zhang W, Ning G, Li X, Yu C, Qin C, Liu J, Tian X, et al. A novel role for thyroid-stimulating hormone: up-regulation of hepatic 3-hydroxy-3-methyl-glutaryl-coenzyme A reductase expression through the cyclic adenosine monophosphate/ protein kinase A/cyclic adenosine monophosphate-responsive element binding protein pathway. Hepatology 201052 1401-1409. (https://doi.org/10.1002/hep.23800)

50 Liu S, Jing F, Yu C, Gao L, Qin Y \& Zhao J. AICAR-induced activation of AMPK inhibits TSH/SREBP-2/HMGCR pathway in liver. PLoS ONE 2015 10 e0124951. (https://doi.org/10.1371/journal.pone.0124951)

51 Moreno-Navarrete JM, Moreno M, Ortega F, Xifra G, Hong S, Asara JM, Serrano JCE, Jové M, Pissios P, Blüher M, et al. TSHB mRNA is linked to cholesterol metabolism in adipose tissue. FASEB Journal $2017 \mathbf{3 1}$ 4482-4491. (https://doi.org/10.1096/fj.201700161R)

52 Comas F, Lluch A, Sabater M, Latorre J, Ortega F, Ricart W, López M, Fernández-Real JM \& Moreno-Navarrete JM. Adipose tissue TSH as a new modulator of human adipocyte mitochondrial function. International Journal of Obesity 201943 1611-1619. (https://doi. org/10.1038/s41366-018-0203-1)

53 Gagnon A, Antunes TT, Ly T, Pongsuwan P, Gavin C, Lochnan HA \& Sorisky A. Thyroid-stimulating hormone stimulates lipolysis in adipocytes in culture and raises serum free fatty acid levels in vivo. Metabolism: Clinical and Experimental 201059 547-553. (https://doi. org/10.1016/j.metabol.2009.08.018) https://ec.bioscientifica.com https://doi.org/10.1530/EC-21-0002 (c) 2022 The authors Published by Bioscientifica Ltd
This work is licensed under a Creative Commons Attribution-NonCommercial-NoDerivatives 4.0 Internationab ficense.ifica . com at 04/26/2023 11:49:36 AM 
54 Song Y, Xu C, Shao S, Liu J, Xing W, Xu J, Qin C, Li C, Hu B, Yi S, et al. Thyroid-stimulating hormone regulates hepatic bile acid homeostasis via SREBP-2/HNF-4a/CYP7A1 axis. Journal of Hepatology 201562 1171-1179. (https://doi.org/10.1016/j.jhep.2014.12.006)

55 Liu XL, He S, Zhang SF, Wang J, Sun XF, Gong CM, Zheng SJ, Zhou JC $\& \mathrm{Xu}$ J. Alteration of lipid profile in subclinical hypothyroidism: a meta-analysis. Medical Science Monitor 201420 1432-1441. (https://doi. org/10.12659/MSM.891163)

56 Gambo Y, Matsumura M \& Fujimori K. Triiodothyronine enhances accumulation of intracellular lipids in adipocytes through thyroid hormone receptor $\alpha$ via direct and indirect mechanisms. Molecular and Cellular Endocrinology 2016431 1-11. (https://doi.org/10.1016/j. mce.2016.04.023)

57 Senese R, Cioffi F, de Lange P, Leanza C, Iannucci LF, Silvestri E, Moreno M, Lombardi A, Goglia F \& Lanni A. Both 3,5-diiodo-Lthyronine and 3,5,3'-triiodo-L-thyronine prevent short-term hepatic lipid accumulation via distinct mechanisms in rats being fed a highfat diet. Frontiers in Physiology 20178 706. (https://doi.org/10.3389/ fphys.2017.00706)

58 Gnoni GV, Rochira A, Leone A, Damiano F, Marsigliante S \& Siculella L. 3,5,3'triiodo-L-thyronine induces SREBP-1 expression by nongenomic actions in human HEP G2 cells. Journal of Cellular Physiology 2012227 2388-2397. (https://doi.org/10.1002/jcp.22974)

59 Han C, Wang J, Li L, Zhang Z, Wang L \& Pan Z. The role of insulin and glucose in goose primary hepatocyte triglyceride accumulation. Journal of Experimental Biology 2009212 1553-1558. (https://doi. org/10.1242/jeb.022210)

60 Fang K, Wu F, Chen G, Dong H, Li J, Zhao Y, Xu L, Zou X \& Lu F. Diosgenin ameliorates palmitic acid-induced lipid accumulation via AMPK/ACC/CPT-1A and SREBP-1C/FAS signaling pathways in LO2 cells. BMC Complementary and Alternative Medicine 201919255. (https://doi.org/10.1186/s12906-019-2671-9)

61 Gauthier K, Billon C, Bissler M, Beylot M, Lobaccaro JM, Vanacker JM \& Samarut J. Thyroid hormone receptor beta (TRbeta) and liver X receptor $(\mathrm{LXR})$ regulate carbohydrate-response element-binding protein (ChREBP) expression in a tissue-selective manner. Journal of Biological Chemistry 2010285 28156-28163. (https://doi.org/10.1074/ jbc.M110.146241)

62 Sanchez-Gurmaches J, Tang Y, Jespersen NZ, Wallace M, Martinez Calejman C, Gujja S, Li H, Edwards YJK, Wolfrum C, Metallo CM, et al. Brown fat AKT2 is a cold-induced kinase that stimulates ChREBP-mediated de novo lipogenesis to optimize fuel storage and thermogenesis. Cell Metabolism 201827 195.e6-209.e6. (https://doi. org/10.1016/j.cmet.2017.10.008)

63 Linden AG, Li S, Choi HY, Fang F, Fukasawa M, Uyeda K, Hammer RE, Horton JD, Engelking LJ \& Liang G. Interplay between ChREBP and SREBP-1c coordinates postprandial glycolysis and lipogenesis in livers of mice. Journal of Lipid Research 201859 475-487. (https://doi. org/10.1194/jlr.M081836)

$64 \mathrm{Liu}$ J, Xu Y, Hu Y \& Wang G. The role of fibroblast growth factor 21 in the pathogenesis of non-alcoholic fatty liver disease and implications for therapy. Metabolism: Clinical and Experimental 201564 380-390. (https://doi.org/10.1016/j.metabol.2014.11.009)

65 Adams AC, Halstead CA, Hansen BC, Irizarry AR, Martin JA, Myers SR, Reynolds VL, Smith HW, Wroblewski VJ \& Kharitonenkov A. LY2405319, an engineered FGF21 variant, improves the metabolic status of diabetic monkeys. PLOS ONE 20138 e65763. (https://doi. org/10.1371/journal.pone.0065763)

66 Véniant MM, Komorowski R, Chen P, Stanislaus S, Winters K, Hager T, Zhou L, Wada R, Hecht R \& Xu J. Long-acting FGF21 has enhanced efficacy in diet-induced obese mice and in obese rhesus monkeys. Endocrinology 2012153 4192-4203. (https://doi.org/10.1210/en.20121211)

67 Gaich G, Chien JY, Fu H, Glass LC, Deeg MA, Holland WL, Kharitonenkov A, Bumol T, Schilske HK \& Moller DE. The effects of LY2405319, an FGF21 analog, in obese human subjects with type 2 diabetes. Cell Metabolism 201318 333-340. (https://doi.org/10.1016/j. cmet.2013.08.005)

68 Xu J, Lloyd DJ, Hale C, Stanislaus S, Chen M, Sivits G, Vonderfecht S, Hecht R, Li YS, Lindberg RA, et al. Fibroblast growth factor 21 reverses hepatic steatosis, increases energy expenditure, and improves insulin sensitivity in diet-induced obese mice. Diabetes 200958 250-259. (https://doi.org/10.2337/db08-0392)

69 Chen W, Hoo RL-c, Konishi M, Itoh N, Lee PC, Ye HY, Lam KS-1 \& Xu A. Growth hormone induces hepatic production of fibroblast growth factor 21 through a mechanism dependent on lipolysis in adipocytes. Journal of Biological Chemistry 2011286 34559-34566. (https://doi. org/10.1074/jbc.M111.285965)

70 Schlein C, Talukdar S, Heine M, Fischer AW, Krott LM, Nilsson SK, Brenner MB, Heeren J \& Scheja L. FGF21 lowers plasma triglycerides by accelerating lipoprotein catabolism in white and brown adipose tissues. Cell Metabolism 201623 441-453. (https://doi.org/10.1016/j. cmet.2016.01.006)

71 Zhang A, Sieglaff DH, York JP, Suh JH, Ayers SD, Winnier GE, Kharitonenkov A, Pin C, Zhang P, Webb P, et al. Thyroid hormone receptor regulates most genes independently of fibroblast growth factor 21 in liver. Journal of Endocrinology 2015224 289-301. (https:// doi.org/10.1530/JOE-14-0440)

72 Adams AC, Astapova I, Fisher FM, Badman MK, Kurgansky KE, Flier JS, Hollenberg AN \& Maratos-Flier E. Thyroid hormone regulates hepatic expression of fibroblast growth factor 21 in a PPARalpha-dependent manner. Journal of Biological Chemistry 2010285 14078-14082. (https://doi.org/10.1074/jbc.C110.107375)

73 Chau MDL, Gao J, Yang Q, Wu Z \& Gromada J. Fibroblast growth factor 21 regulates energy metabolism by activating the AMPK-SIRT1PGC-1alpha pathway. PNAS 2010107 12553-12558. (https://doi. org/10.1073/pnas.1006962107)

74 Iizuka K, Takao K, Kato T, Horikawa Y \& Takeda J. ChREBP reciprocally regulates liver and plasma triacylglycerol levels in different manners. Nutrients 201810 1699. (https://doi.org/10.3390/nu10111699)

75 Benhamed F, Denechaud PD, Lemoine M, Robichon C, Moldes M, Bertrand-Michel J, Ratziu V, Serfaty L, Housset C, Capeau J, et al. The lipogenic transcription factor ChREBP dissociates hepatic steatosis from insulin resistance in mice and humans. Journal of Clinical Investigation 2012122 2176-2194. (https://doi.org/10.1172/ JCI41636)

76 Domouzoglou EM, Fisher FM, Astapova I, Fox EC, Kharitonenkov A, Flier JS, Hollenberg AN \& Maratos-Flier E. Fibroblast growth factor 21 and thyroid hormone show mutual regulatory dependency but have independent actions in vivo. Endocrinology 2014155 2031-2040. (https://doi.org/10.1210/en.2013-1902)

77 Wang G, Liu J, Yang N, Hu Y, Zhang H, Miao L, Yao Z \& Xu Y. Levothyroxine treatment restored the decreased circulating fibroblast growth factor 21 levels in patients with hypothyroidism. European Journal of Internal Medicine 201631 94-98. (https://doi.org/10.1016/j. ejim.2016.03.028)

78 Xiao F, Zeng J, Huang P, Yan B, Zeng X, Liu C, Shi X, Wang L, Song H, Lin $\mathrm{M}$, et al. Independent association of serum fibroblast growth factor 21 levels with impaired liver enzymes in hyperthyroid patients. Frontiers in Endocrinology 20189 800. (https://doi.org/10.3389/ fendo.2018.00800)

79 Bonde Y, Breuer O, Lütjohann D, Sjöberg S, Angelin B \& Rudling M. Thyroid hormone reduces PCSK9 and stimulates bile acid synthesis in humans. Journal of Lipid Research 201455 2408-2415. (https://doi. org/10.1194/jlr.M051664)

80 Lee Y, Park YJ, Ahn HY, Lim JA, Park KU, Choi SH, Park DJ, Oh BC, Jang HC \& Yi KH. Plasma FGF21 levels are increased in patients with hypothyroidism independently of lipid profile. Endocrine Journal 2013 60 977-983. (https://doi.org/10.1507/endocrj.ej12-0427)

81 Lundåsen T, Gälman C, Angelin B \& Rudling M. Circulating intestinal fibroblast growth factor 19 has a pronounced diurnal variation and modulates hepatic bile acid synthesis in man. Journal of Internal 
Medicine 2006260 530-536. (https://doi.org/10.1111/j.13652796.2006.01731.x)

82 Angelin B, Larsson TE \& Rudling M. Circulating fibroblast growth factors as metabolic regulators - a critical appraisal. Cell Metabolism 201216 693-705. (https://doi.org/10.1016/j.cmet.2012.11.001)

83 Lai Y, Wang H, Xia X, Wang Z, Fan C, Wang H, Zhang H, Ding S, Teng W \& Shan Z. Serum fibroblast growth factor 19 is decreased in patients with overt hypothyroidism and subclinical hypothyroidism. Medicine 201695 e5001. (https://doi.org/10.1097/ MD.0000000000005001)

84 Miyata M, Hata T, Yamazoe Y \& Yoshinari K. SREBP-2 negatively regulates FXR-dependent transcription of FGF19 in human intestinal cells. Biochemical and Biophysical Research Communications 2014443 477-482. (https://doi.org/10.1016/j.bbrc.2013.11.126)

85 Yap CS, Sinha RA, Ota S, Katsuki M \& Yen PM. Thyroid hormone negatively regulates CDX2 and SOAT2 mRNA expression via induction of miRNA-181d in hepatic cells. Biochemical and Biophysical Research Communications 2013440 635-639. (https://doi.org/10.1016/j. bbrc.2013.09.116)

86 Zheng Y, Zhao C, Zhang N, Kang W, Lu R, Wu H, Geng Y, Zhao Y \& $\mathrm{Xu}$ X. Serum microRNA miR-206 is decreased in hyperthyroidism and mediates thyroid hormone regulation of lipid metabolism in HepG2 human hepatoblastoma cells. Molecular Medicine Reports 201817 5635-5641. (https://doi.org/10.3892/mmr.2018.8633)

87 Sun C, Liu W, Lu Z, Li Y, Liu S, Tang Z, Yan Y, Li Z, Feng H, Zhang D, et al. Hepatic miR-378 modulates serum cholesterol levels by regulating hepatic bile acid synthesis. Theranostics 202111 4363-4380. (https://doi.org/10.7150/thno.53624)

88 Zhang L, Wu K, Bo T, Zhou L, Gao L, Zhou X \& Chen W. Integrated microRNA and proteome analysis reveal a regulatory module in hepatic lipid metabolism disorders in mice with subclinical hypothyroidism. Experimental and Therapeutic Medicine 202019 897-906. (https://doi.org/10.3892/etm.2019.8281)

89 Canuel M, Sun X, Asselin MC, Paramithiotis E, Prat A \& Seidah NG. Proprotein convertase subtilisin/kexin type 9 (PCSK9) can mediate degradation of the low density lipoprotein receptor-related protein 1 (LRP-1). PLoS ONE 20138 e64145. (https://doi.org/10.1371/journal. pone.0064145)

90 Lee JS, Mukhopadhyay P, Matyas C, Trojnar E, Paloczi J, Yang YR, Blank BA, Savage C, Sorokin AV, Mehta NN, et al. PCSK9 inhibition as a novel therapeutic target for alcoholic liver disease. Scientific Reports 20199 17167. (https://doi.org/10.1038/s41598-019-53603-6)

91 Ruscica M, Ferri N, Macchi C, Meroni M, Lanti C, Ricci C, Maggioni M, Fracanzani AL, Badiali S, Fargion S, et al. Liver fat accumulation is associated with circulating PCSK9. Annals of Medicine 201648 384-391. (https://doi.org/10.1080/07853890.2016.1188328)

92 Jing Y, Hu T, Lin C, Xiong Q, Liu F, Yuan J, Zhao X \& Wang R. Resveratrol downregulates PCSK9 expression and attenuates steatosis through estrogen receptor $\alpha$-mediated pathway in L02 cells. European Journal of Pharmacology 2019855 216-226. (https://doi.org/10.1016/j. ejphar.2019.05.019)

93 Gong Y, Ma Y, Ye Z, Fu Z, Yang P, Gao B, Guo W, Hu D, Ye J, Ma S, et al. Thyroid stimulating hormone exhibits the impact on LDLR/ LDL-c via up-regulating hepatic PCSK9 expression. Metabolism: Clinical and Experimental 201776 32-41. (https://doi.org/10.1016/j. metabol.2017.07.006)

94 Yildirim AM, Koca AO, Beyan E, Dogan O, Karakaya S, Aksoz Z \& Ertuğrul DT. Association of serum proprotein convertase subtilisin/ kexin type 9 (PCSK9) level with thyroid function disorders. European Review for Medical and Pharmacological Sciences 202125 5511-5517. (https://doi.org/10.26355/eurrev_202109_26662)

95 Schaap FG, Rensen PCN, Voshol PJ, Vrins C, van der Vliet HN, Chamuleau RAFM, Havekes LM, Groen AK \& van Dijk KW. ApoAV reduces plasma triglycerides by inhibiting very low density lipoprotein-triglyceride (VLDL-TG) production and stimulating lipoprotein lipase-mediated VLDL-TG hydrolysis. Journal of Biological
Chemistry 2004279 27941-27947. (https://doi.org/10.1074/jbc. M403240200)

96 Gjedde S, Gormsen LC, Rungby J, Nielsen S, Jørgensen JOL, Pedersen SB, Riis AL, Weeke J \& Møller N. Decreased lipid intermediate levels and lipid oxidation rates despite normal lipolysis in patients with hypothyroidism. Thyroid 201020 843-849. (https://doi. org/10.1089/thy.2009.0212)

97 Prieur X, Huby T, Coste H, Schaap FG, Chapman MJ \& Rodríguez JC. Thyroid hormone regulates the hypotriglyceridemic gene APOA5. Journal of Biological Chemistry 2005280 27533-27543. (https://doi. org/10.1074/jbc.M503139200)

98 Martínez-Triguero ML, Hernández-Mijares A, Nguyen TT, Muñoz ML, Peña H, Morillas C, Lorente D, Lluch I \& Molina E. Effect of thyroid hormone replacement on lipoprotein (a), lipids, and apolipoproteins in subjects with hypothyroidism. Mayo Clinic Proceedings 199873 837-841. (https://doi.org/10.4065/73.9.837)

99 Sigal GA, Medeiros-Neto G, Vinagre JC, Diament J \& Maranhão RC. Lipid metabolism in subclinical hypothyroidism: plasma kinetics of triglyceride-rich lipoproteins and lipid transfers to high-density lipoprotein before and after levothyroxine treatment. Thyroid 201121 347-353. (https://doi.org/10.1089/thy.2010.0313)

100 Ito M, Takamatsu J, Sasaki I, Hiraiwa T, Fukao A, Murakami Y, Isotani H, Miyauchi A, Kuma K \& Hanafusa T. Disturbed metabolism of remnant lipoproteins in patients with subclinical hypothyroidism. American Journal of Medicine 2004117 696-699. (https://doi. org/10.1016/j.amjmed.2004.04.027)

101 Moon JH, Kim HJ, Kim HM, Choi SH, Lim S, Park YJ, Jang HC \& Cha BS. Decreased expression of hepatic low-density lipoprotein receptor-related protein 1 in hypothyroidism: a novel mechanism of atherogenic dyslipidemia in hypothyroidism. Thyroid 201323 1057-1065. (https://doi.org/10.1089/thy.2012.0457)

102 Costales P, Castellano J, Revuelta-López E, Cal R, Aledo R, Llampayas O, Nasarre L, Juarez C, Badimon L \& Llorente-Cortés V. Lipopolysaccharide downregulates CD91/low-density lipoprotein receptor-related protein 1 expression through SREBP-1 overexpression in human macrophages. Atherosclerosis 2013227 79-88. (https://doi. org/10.1016/j.atherosclerosis.2012.12.021)

103 Costales P, Aledo R, Vérnia S, Das A, Shah VH, Casado M, Badimon L \& Llorente-Cortés V. Selective role of sterol regulatory element binding protein isoforms in aggregated LDL-induced vascular low density lipoprotein receptor-related protein-1 expression. Atherosclerosis 2010 213 458-468. (https://doi.org/10.1016/j.atherosclerosis.2010.09.034)

104 Ma S, Jing F, Xu C, Zhou L, Song Y, Yu C, Jiang D, Gao L, Li Y, Guan Q, et al. Thyrotropin and obesity: increased adipose triglyceride content through glycerol-3-phosphate acyltransferase 3. Scientific Reports 2015 5 7633. (https://doi.org/10.1038/srep07633)

105 Yan F, Wang Q, Lu M, Chen W, Song Y, Jing F, Guan Y, Wang L, Lin Y, Bo T, et al. Thyrotropin increases hepatic triglyceride content through upregulation of SREBP-1c activity. Journal of Hepatology $2014 \mathbf{6 1}$ 1358-1364. (https://doi.org/10.1016/j.jhep.2014.06.037)

106 van Tienhoven-Wind LJN, Dallinga-Thie GM \& Dullaart RPF. Higher plasma ApoE levels are associated with low-normal thyroid function: studies in diabetic and nondiabetic subjects. Hormone and Metabolic Research 201648 462-467. (https://doi.org/10.1055/s-0042-102883)

107 Jung KY, Ahn HY, Han SK, Park YJ, Cho BY \& Moon MK. Association between thyroid function and lipid profiles, apolipoproteins, and high-density lipoprotein function. Journal of Clinical Lipidology 2017 11 1347-1353. (https://doi.org/10.1016/j.jacl.2017.08.015)

108 Fugier C, Tousaint JJ, Prieur X, Plateroti M, Samarut J \& Delerive P. The lipoprotein lipase inhibitor ANGPTL3 is negatively regulated by thyroid hormone. Journal of Biological Chemistry 2006281 11553-11559. (https://doi.org/10.1074/jbc.M512554200)

109 Li H, Xu M, Zhao L, Xia H, Li Y, Hong X, Deng X, Yuan J, Ding Y, Guo C, et al. Decreased circulating levels of ANGPTL8 in Graves' disease patients. Hormones 201918 189-195. (https://doi.org/10.1007/ s42000-019-00095-8) 
110 Stitziel NO, Khera AV, Wang X, Bierhals AJ, Vourakis AC, Sperry AE, Natarajan P, Klarin D, Emdin CA, Zekavat SM, et al. ANGPTL3 deficiency and protection against coronary artery disease. Journal of the American College of Cardiology 201769 2054-2063. (https://doi. org/10.1016/j.jacc.2017.02.030)

111 Wang Y, Gusarova V, Banfi S, Gromada J, Cohen JC \& Hobbs HH. Inactivation of ANGPTL3 reduces hepatic VLDL-triglyceride secretion. Journal of Lipid Research 201556 1296-1307. (https://doi.org/10.1194/ jlr.M054882)

112 Reimund M, Kovrov O, Olivecrona G \& Lookene A. Lipoprotein lipase activity and interactions studied in human plasma by isothermal titration calorimetry. Journal of Lipid Research 201758 279-288. (https://doi.org/10.1194/jlr.D071787)

113 Morinaga J, Zhao J, Endo M, Kadomatsu T, Miyata K, Sugizaki T, Okadome Y, Tian Z, Horiguchi H, Miyashita K, et al. Association of circulating ANGPTL 3, 4, and 8 levels with medical status in a population undergoing routine medical checkups: a cross-sectional study. PLoS ONE 201813 e0193731. (https://doi.org/10.1371/journal. pone.0193731)

114 Liu J, Afroza H, Rader DJ \& Jin W. Angiopoietin-like protein 3 inhibits lipoprotein lipase activity through enhancing its cleavage by proprotein convertases. Journal of Biological Chemistry 2010285 27561-27570. (https://doi.org/10.1074/jbc.M110.144279)

115 Mysling S, Kristensen KK, Larsson M, Kovrov O, Bensadouen A, Jørgensen TJ, Olivecrona G, Young SG \& Ploug M. The angiopoietinlike protein ANGPTL4 catalyzes unfolding of the hydrolase domain in lipoprotein lipase and the endothelial membrane protein GPIHBP1 counteracts this unfolding. eLife 20165 e20958. (https://doi org/10.7554/eLife.20958)

116 Minicocci I, Tikka A, Poggiogalle E, Metso J, Montali A, Ceci F, Labbadia G, Fontana M, Di Costanzo A, Maranghi M, et al. Effects of angiopoietin-like protein 3 deficiency on postprandial lipid and lipoprotein metabolism. Journal of Lipid Research 201657 1097-1107. (https://doi.org/10.1194/jlr.P066183)

117 Tikkanen E, Minicocci I, Hällfors J, Di Costanzo A, D'Erasmo L, Poggiogalle E, Donini LM, Würtz P, Jauhiainen M, Olkkonen VM, et al. Metabolomic signature of angiopoietin-like protein 3 deficiency in fasting and postprandial state. Arteriosclerosis, Thrombosis, and Vascular Biology 201939 665-674. (https://doi.org/10.1161/ ATVBAHA.118.312021)

118 Xu YX, Redon V, Yu H, Querbes W, Pirruccello J, Liebow A, Deik A, Trindade K, Wang X, Musunuru K, et al. Role of angiopoietin-like 3 (ANGPTL3) in regulating plasma level of low-density lipoprotein cholesterol. Atherosclerosis 2018268 196-206. (https://doi. org/10.1016/j.atherosclerosis.2017.08.031)

119 Yang L, Yin R, Wang Z, Wang X, Zhang Y \& Zhao D. Circulating Angptl3 and Angpt18 are increased in patients with hypothyroidism. BioMed Research International 20192019 3814687. (https://doi. org $/ 10.1155 / 2019 / 3814687$ )

120 Shimamura M, Matsuda M, Yasumo H, Okazaki M, Fujimoto K, Kono K, Shimizugawa T, Ando Y, Koishi R, Kohama T, et al. Angiopoietin-like protein3 regulates plasma HDL cholesterol through suppression of endothelial lipase. Arteriosclerosis, Thrombosis, and Vascular Biology 200727 366-372. (https://doi.org/10.1161/01. ATV.0000252827.51626.89)

121 Izumi R, Kusakabe T, Noguchi M, Iwakura H, Tanaka T, Miyazawa T, Aotani D, Hosoda K, Kangawa K \& Nakao K. CRISPR/Cas9-mediated knockout suppresses plasma triglyceride concentrations and adiposity in rats. Journal of Lipid Research 201859 1575-1585. (https://doi. org/10.1194/jlr.M082099)

122 Wang Y, Quagliarini F, Gusarova V, Gromada J, Valenzuela DM, Cohen JC \& Hobbs HH. Mice lacking ANGPTL8 (Betatrophin) manifest disrupted triglyceride metabolism without impaired glucose homeostasis. PNAS 2013110 16109-16114. (https://doi.org/10.1073/ pnas.1315292110)
123 Haller JF, Mintah IJ, Shihanian LM, Stevis P, Buckler D, AlexaBraun CA, Kleiner S, Banfi S, Cohen JC, Hobbs HH, et al. ANGPTL8 requires ANGPTL3 to inhibit lipoprotein lipase and plasma triglyceride clearance. Journal of Lipid Research 201758 1166-1173. (https://doi. org/10.1194/jlr.M075689)

124 Quagliarini F, Wang Y, Kozlitina J, Grishin NV, Hyde R, Boerwinkle E, Valenzuela DM, Murphy AJ, Cohen JC \& Hobbs HH. Atypical angiopoietin-like protein that regulates ANGPTL3. PNAS 2012109 19751-19756. (https://doi.org/10.1073/pnas.1217552109)

125 Chi X, Britt EC, Shows HW, Hjelmaas AJ, Shetty SK, Cushing EM, Li W, Dou A, Zhang R \& Davies BSJ. ANGPTL8 promotes the ability of ANGPTL3 to bind and inhibit lipoprotein lipase. Molecular Metabolism 20176 1137-1149. (https://doi.org/10.1016/j. molmet.2017.06.014)

126 Chung HS, Lee MJ, Hwang SY, Lee HJ, Yoo HJ, Seo JA, Kim SG, Kim NH, Baik SH, Choi DS, et al. Circulating angiopoietin-like protein 8 (ANGPTL8) and ANGPTL3 concentrations in relation to anthropometric and metabolic profiles in Korean children: a prospective cohort study. Cardiovascular Diabetology 2016151. (https://doi.org/10.1186/s12933-015-0324-y)

127 Gusarova V, Banfi S, Alexa-Braun CA, Shihanian LM, Mintah IJ, Lee JS, Xin Y, Su Q, Kamat V, Cohen JC, et al. ANGPTL8 blockade with a monoclonal antibody promotes triglyceride clearance, energy expenditure, and weight loss in mice. Endocrinology 2017158 1252-1259. (https://doi.org/10.1210/en.2016-1894)

$128 \mathrm{Fu}$ Z, Abou-Samra AB \& Zhang R. A lipasin/Angpt18 monoclonal antibody lowers mouse serum triglycerides involving increased postprandial activity of the cardiac lipoprotein lipase. Scientific Reports 20155 18502. (https://doi.org/10.1038/srep18502)

129 Tseng YH, Ke PY, Liao CJ, Wu SM, Chi HC, Tsai CY, Chen CY, Lin YH $\&$ Lin $\mathrm{KH}$. Chromosome 19 open reading frame 80 is upregulated by thyroid hormone and modulates autophagy and lipid metabolism. Autophagy 201410 20-31. (https://doi.org/10.4161/auto.26126)

130 Ren G, Kim JY \& Smas CM. Identification of RIFL, a novel adipocyteenriched insulin target gene with a role in lipid metabolism. American Journal of Physiology: Endocrinology and Metabolism 2012303 E334-E351. (https://doi.org/10.1152/ajpendo.00084.2012)

131 Fenzl A, Itariu BK, Kosi L, Fritzer-Szekeres M, Kautzky-Willer A, Stulnig TM \& Kiefer FW. Circulating betatrophin correlates with atherogenic lipid profiles but not with glucose and insulin levels in insulin-resistant individuals. Diabetologia 201457 1204-1208. (https:// doi.org/10.1007/s00125-014-3208-x)

132 Lim JA, Kim HJ, Ahn HY, Park KU, Yi KH, Park DJ, Jang HC \& Park YJ. Influence of thyroid dysfunction on serum levels of angiopoietin-like protein 6. Metabolism: Clinical and Experimental 201564 1279-1283. (https://doi.org/10.1016/j.metabol.2015.06.015)

133 Namkung J, Sohn JH, Chang JS, Park SW, Kim JY, Koh SB, Kong ID $\&$ Park KS. Increased serum angiopoietin-like 6 ahead of metabolic syndrome in a prospective cohort study. Diabetes and Metabolism Journal 201943 521-529. (https://doi.org/10.4093/dmj.2018.0080)

134 Kang SG, Yi HS, Choi MJ, Ryu MJ, Jung S, Chung HK, Chang JY, Kim YK, Lee SE, Kim HW, et al. ANGPTL6 expression is coupled with mitochondrial OXPHOS function to regulate adipose FGF21. Journal of Endocrinology 2017233 105-118. (https://doi.org/10.1530/JOE-160549)

135 Ge H, Yang G, Huang L, Motola DL, Pourbahrami T \& Li C. Oligomerization and regulated proteolytic processing of angiopoietinlike protein 4. Journal of Biological Chemistry 2004279 2038-2045. (https://doi.org/10.1074/jbc.M307583200)

136 TG and HDL Working Group of the Exome Sequencing Project, National Heart, Lung, and Blood Institute, Crosby J, Peloso GM, Auer PL, Crosslin DR, Stitziel NO, Lange LA, Lu Y, Tang ZZ, Zhang H, et al. Loss-of-function mutations in APOC3, triglycerides, and coronary disease. New England Journal of Medicine $201437122-31$. (https://doi.org/10.1056/NEJMoa1307095) https://ec.bioscientifica.com https://doi.org/10.1530/EC-21-0002 (c) 2022 The authors Published by Bioscientifica Ltd
This work is licensed under a Creative Commons Attribution-NonCommercial-NoDerivatives 4.0 International License.ifica com at $04 / 26 / 2023$ 11:49:36AM 
137 van Tienhoven-Wind LJN, Perton FG \& Dullaart RPF. Pre- $\beta$ HDL formation relates to high-normal free thyroxine in type 2 diabetes mellitus. Clinical Biochemistry 201649 41-46. (https://doi. org/10.1016/j.clinbiochem.2015.08.024)

138 Boone LR, Lagor WR, Moya Mde L, Niesen MI, Rothblat GH \& Ness GC. Thyroid hormone enhances the ability of serum to accept cellular cholesterol via the ABCA1 transporter. Atherosclerosis 2011218 77-82. (https://doi.org/10.1016/j.atherosclerosis.2011.04.028)

139 Yang N, Yao Z, Miao L, Liu J, Gao X, Xu Y \& Wang G. Homocysteine diminishes apolipoprotein A-I function and expression in patients with hypothyroidism: a cross-sectional study. Lipids in Health and Disease 201615 123. (https://doi.org/10.1186/s12944-016-0293-5)

140 Sigal GA, Tavoni TM, Silva BMO, Kalil Filho R, Brandão LG \& Maranhão RC. Effects of short-term hypothyroidism on the lipid transfer to high-density lipoprotein and other parameters related to lipoprotein metabolism in patients submitted to thyroidectomy for thyroid cancer. Thyroid 201929 53-58. (https://doi.org/10.1089/ thy.2018.0190)

141 van der Boom T, Jia C, Lefrandt JD, Connelly MA, Links TP, Tietge UJF \& Dullaart RPF. HDL cholesterol efflux capacity is impaired in severe short-term hypothyroidism despite increased HDL cholesterol. Journal of Clinical Endocrinology and Metabolism 2020105 e3355-e3362. (https://doi.org/10.1210/clinem/dgaa411)

142 Ridgway ND \& Dolphin PJ. Serum activity and hepatic secretion of lecithin:cholesterol acyltransferase in experimental hypothyroidism and hypercholesterolemia. Journal of Lipid Research 198526 1300-1313. (https://doi.org/10.1016/S0022-2275(20)34256-5)

143 Kuusi T, Saarinen P \& Nikkilä EA. Evidence for the role of hepatic endothelial lipase in the metabolism of plasma high density lipoprotein2 in man. Atherosclerosis 198036 589-593. (https://doi. org/10.1016/0021-9150(80)90251-8)
144 McGowan A, Widdowson WM, O’Regan A, Young IS, Boran G, McEneny J \& Gibney J. Postprandial studies uncover differing effects on HDL particles of overt and subclinical hypothyroidism. Thyroid 201626 356-364. (https://doi.org/10.1089/thy.2015.0443)

145 Ness GC \& Lopez D. Transcriptional regulation of rat hepatic lowdensity lipoprotein receptor and cholesterol 7 alpha hydroxylase by thyroid hormone. Archives of Biochemistry and Biophysics 1995323 404-408. (https://doi.org/10.1006/abbi.1995.0061)

146 Bonde Y, Plösch T, Kuipers F, Angelin B \& Rudling M. Stimulation of murine biliary cholesterol secretion by thyroid hormone is dependent on a functional ABCG5/G8 complex. Hepatology 201256 1828-1837. (https://doi.org/10.1002/hep.25861)

147 Johansson L, Rudling M, Scanlan TS, Lundåsen T, Webb P, Baxter J, Angelin B \& Parini P. Selective thyroid receptor modulation by GC-1 reduces serum lipids and stimulates steps of reverse cholesterol transport in euthyroid mice. PNAS 2005102 10297-10302. (https:// doi.org/10.1073/pnas.0504379102)

148 Skoczyńska A, Wojakowska A, Turczyn B, Zatońska K, Wołyniec M, Rogala N, Szuba A \& Bednarek-Tupikowska G. Serum lipid transfer proteins in hypothyreotic patients are inversely correlated with thyroid-stimulating hormone (TSH) levels. Medical Science Monitor 201622 4661-4669. (https://doi.org/10.12659/msm.898134)

149 Triolo M, Kwakernaak AJ, Perton FG, de Vries R, DallingaThie GM \& Dullaart RPF. Low normal thyroid function enhances plasma cholesteryl ester transfer in type 2 diabetes mellitus. Atherosclerosis 2013228 466-471. (https://doi.org/10.1016/j. atherosclerosis.2013.03.009)

150 Rhainds D \& Tardif JC. From HDL-cholesterol to HDL-function: cholesterol efflux capacity determinants. Current Opinion in Lipidology 201930 101-107. (https://doi.org/10.1097/ MOL.0000000000000589)

Received in final form 27 December 2021

Accepted 11 January 2022

Accepted Manuscript published online 11 January 2022 https://ec.bioscientifica.com https://doi.org/10.1530/EC-21-0002 (c) 2022 The authors Published by Bioscientifica Ltd
This work is licensed under a Creative Commons Attribution-NonCommercial-NoDerivatives 4.0 Internationab ficense.ifica . com at 04/26/2023 11:49:36 AM 